Article

\title{
Battery Scrap and Biochar Utilization for Improved Metal Recoveries in Nickel Slag Cleaning Conditions
}

\author{
Katri Avarmaa ${ }^{1, *}$, , Marko Järvenpää ${ }^{1,2}$, Lassi Klemettinen ${ }^{1}\left(\mathbb{D}\right.$, Miikka Marjakoski ${ }^{3}$, \\ Pekka Taskinen ${ }^{1}\left(\mathbb{D}\right.$, Daniel Lindberg ${ }^{1}(\mathbb{D})$ and Ari Jokilaakso ${ }^{1} \mathbb{D}$ \\ 1 Department of Chemical and Metallurgical Engineering, School of Chemical Engineering, Aalto University, \\ P.O. Box 16100, FI-00076 Aalto, Finland; marko.jarvenpaa@murata.com (M.J.); \\ lassi.klemettinen@aalto.fi (L.K.); pekka.taskinen@aalto.fi (P.T.); daniel.k.lindberg@aalto.fi (D.L.); \\ ari.jokilaakso@aalto.fi (A.J.) \\ 2 Murata Electronics Oy, Myllynkivenkuja 6, 01621 Vantaa, Finland \\ 3 Boliden Harjavalta, Teollisuuskatu 1, 29200 Harjavalta, Finland; miikka.marjakoski@boliden.com \\ * Correspondence: katri.avarmaa@aalto.fi
}

Received: 20 October 2020; Accepted: 25 November 2020; Published: 2 December 2020

check for updates

\begin{abstract}
Cobalt is a critical, high-value metal used extensively in batteries and other sustainable technologies. To secure its supply in future, it is utmost important to recover cobalt efficiently from industrial wastes and recycled End-of-Life batteries. This study aims at finding ways to improve the reduction of cobalt as well as valuable metals nickel and copper in nickel slag cleaning furnace conditions by using both traditional fossil-based coke and a more sustainable option, low- $\mathrm{CO}_{2}$ footprint biochar, as reductants. A cobalt-rich fraction of battery scrap $(25.5 \mathrm{wt} \% \mathrm{Co})$ was also used as a secondary feed. The experimental technique consisted of reduction experiments with different times at $1400{ }^{\circ} \mathrm{C}$ under inert atmosphere, quick quenching and Electron Probe X-ray Microanalysis. The use of biochar resulted in faster reaction kinetics in the reduction process, compared to coke. Moreover, the presence of battery scrap had a clear impact on the behavior and reduction kinetics of the elements and/or enhanced settling and separation of matte and slag. The addition of scrap increased notably the distribution coefficients of the valuable metals but consequently also the iron concentration in matte which is the thermodynamic constraint of the slag cleaning process.
\end{abstract}

Keywords: energy storage materials; bio reducers; reduction kinetics; circular economy

\section{Introduction}

Cobalt has many statuses: a critical raw material by the European Union [1,2], strategic mineral by the United States already since 1980s [3,4] and conflict mineral due to its unstable main extraction location; the Democratic Republic of the Congo [5]. Already based on these, its economic and environmental importance in our contemporary society is clear. The demand for cobalt is growing and efficient recycling is needed in order to secure its availability.

In the Earth's crust, cobalt is highly scattered and consequently found in a variety of minerals, especially associated with copper and nickel ores. According to estimations $[1,6], 40-50 \%$ of the world's cobalt is a by-product of nickel production. Nickel sulfide concentrates (10-20 wt \% Ni and $0.3-0.8 \mathrm{wt} \%$ Co [6,7]) are typically processed with pyrometallurgical techniques, such as the Direct Outotec Nickel technology (DON) [8,9]. The direct-to-nickel DON-technology is a flash smelting process combined with slag cleaning in an electric furnace (EF). It produces high-grade nickel matte in flash smelting furnace (FSF) and EF matte, which recovers most of the nickel and other valuable minor elements such as Co, PGM's, Au and Ag from the FSF slag. The EF matte is a metallic phase with a minor concentration of dissolved sulfur. Compared to traditional smelting-converting route, cobalt and other valuable 
metal recoveries are significantly better in the DON-process due to the absence of the converting stage and slag circulation The trend in all nickel smelting technologies has been towards higher matte grades (lower $w \mathrm{t} \%$ Fe in matte) and thus all modern smelters employ some slag cleaning stage [10].

The aim of slag cleaning is to recover the maximum amounts of valuable metals, such as Co, $\mathrm{Ni}$ and $\mathrm{Cu}$, in EF matte produced, while simultaneously keeping its iron content as low as possible. Because of the thermodynamic properties of the present metals, such as chemically similar reduction behavior of cobalt and iron, some losses of valuable metals are inevitable in the slag cleaning [11]. Nickel, cobalt and copper occur in molten FSF slags in two different forms: as mechanically entrapped matte droplets and as chemically dissolved oxides, $\mathrm{CoO}, \mathrm{NiO}$ and $\mathrm{Cu}_{2} \mathrm{O}$. In order to recover elements from both states, the dissolved oxides need to be reduced from the slag, typically by using fossil-based coke and the mechanically entrapped matte/metal droplets need to separate, grow and settle into the matte at the bottom of the furnace. Bio-based reductants are already considered as promising options to replace coal or coke in various metal reduction processes, including iron/steel making [12-14] and non-ferrous processing $[15,16]$. In ferrous metallurgy, the use of biochar or bio-coke (biochar mixed with coal) to replace partly or entirely the traditional coal/coke has become a research hotspot [14]. The properties of biochar, such as calorific value, fixed carbon content and impurities, rely highly on its biomass source but especially its production technology [12-14].

In addition to slag cleaning, also Ni-Co containing waste recovery in EF is an attractive option that can be employed more extensively in the future. This applies also to Co-rich Waste Electric and Electronic Equipment (WEEE), such as energy storage materials. In 2016, approximately 50\% of the produced cobalt was employed to battery chemicals [1], for example, for lithium nickel manganese cobalt oxide, lithium nickel cobalt aluminum oxide and lithium cobalt oxide batteries containing 10-30 wt\%, 10-15 wt\% and approximately $60 \mathrm{wt} \%$ of cobalt, respectively [17]. Cobalt demand will increase rapidly at least for the next 10 years as lithium ion battery (LiB) demand and sustainable energy production grow, according to the EU [1]. An annual growth rate of $7-13 \%$ for cobalt demand, mostly by electric vehicles (EVs), is forecasted every year until 2030. Thus, optional resources, process development, substitutional materials and technologies for cobalt and many other metals are needed in order to keep up in the development pace towards a more sustainable society.

Today, the recycling rates vary around the world: in United States, 20-30\% of cobalt metal and chemicals are produced from recycled EoL (End-of-Life) scraps $[6,18]$. In China, the recycling of cobalt is estimated to be approximately 35\%, although only $2 \%$ of waste batteries were recycled in 2013 [19] and in Germany, the end-of-life recycling for cobalt was evaluated as 14\% from EoL batteries [20]. Recycling technologies for EoL LIBs exist [21-23] and currently the EoL batteries are treated in primary nickel smelters or purpose-built recycling (secondary) smelters [23,24]. The relevance of the battery recycling is going to increase as the EoL battery availability expands in the near future. One readily available option would be to use existing pyrometallurgical processes, such as the slag cleaning EF in the DON smelter. Consequently, to improve the environmental targets and decrease the dependency of slag cleaning process on fossil fuels, utilizing biochar instead of coke would be a valid option.

The reduction kinetics of nickel smelting slags regarding cobalt, nickel and copper recoveries as a function of time have been investigated very limitedly [25-28]. Studies determining the rate controlling steps of reduction of iron oxides [29] and iron-silicate slags [30,31] exist and most of them suggest that the carbon gasification/the Boudouard reaction is the controlling step but also chemical reaction and mass transfer, that is, diffusion and convection mechanisms, have been proposed [32,33]. Wang [34] presented that nickel recovery was increased when the initial sulfur in slag decreased, whereas sulfur did not have a noticeable influence on the recoveries of cobalt, copper and iron. Zhou et al. [33] investigated copper and iron reduction from copper converter slag at $1250{ }^{\circ} \mathrm{C}$ employing anthracite as reductant. Copper concentration was reduced from 4.49 to $0.32 \mathrm{wt} \%$ in $10 \mathrm{~min}$ and they proposed that after magnetite was reduced to iron, foaming slag was formed in the upper slag layer, causing increase in the copper concentration in slag after 10 min of reduction time. Banks and Harrison [35] investigated carbothermic reduction of non-ferrous metals, including $\mathrm{Cu}$ and $\mathrm{Ni}$, from secondary 
copper smelting slags as a function of time at $1350^{\circ} \mathrm{C}$. Sorokin et al. [36] computationally investigated $\mathrm{Ni}$ and Co recoveries in nickel slag cleaning conditions at $1300{ }^{\circ} \mathrm{C}$ with two reductants: coal and natural gas. Pan et al. [37] investigated the optimal parameters (basicity, coal addition, reduction period and temperature) for 'selective reduction-magnetic separation' technique to utilize nickel slags.

Matusewicz and Mounsey [27] investigated cobalt recoveries from different copper and nickel smelting slags under reducing conditions in a pilot-scale Ausmelt furnace $(100 \mathrm{~kg} / \mathrm{h})$ and in laboratoryscale experiments $(500 \mathrm{~g}$ ). They used coal as a reductant with $30 \mathrm{~kg} / \mathrm{h}$ feed rate in the pilot-scale experiments. The influence of different parameters (reduction rate, the use of sulfidizing agent and fluxes) on the cobalt behavior was investigated. Banda et al. [38] investigated the reduction of cobalt and copper from copper smelting slags at $4.33 \times 10^{-9}$ atm oxygen partial pressure by employing a solid carbon reductant. Copper recovery increased in $15 \mathrm{~min}$ from 70\% to 95\%, after which it decreased to $85 \%$ at 60 min reduction. Cobalt recovery increased in $15 \mathrm{~min}$ from 35\% to 65\% and into maximum recovery of $75 \%$ at $30 \mathrm{~min}$. Kucharski et al. [39] investigated copper reduction from direct-to-copper smelting slag by a graphite penetrator at $1300{ }^{\circ} \mathrm{C}$ under nitrogen gas flow. Copper concentration in slag was decreased from $14.3 \mathrm{wt} \%$ to $0.4-1.5 \mathrm{wt} \%$. Gonzales [40] investigated Chilean copper slag reduction in an alumina crucible by a coke reductant and calcia as flux at $1460{ }^{\circ} \mathrm{C}$ in an electric furnace. Two recent studies by Ruismäki et al. [41,42] investigated the reduction of valuable metals from DON-slag mixed with nickel concentrate under a $\mathrm{CH}_{4}(5 \mathrm{vol} \%)-\mathrm{N}_{2}$ gas atmosphere at $1400{ }^{\circ} \mathrm{C}$ [41] and from DON-slag mixed with graphite-containing froth flotation fraction from LIB scrap at 1350 and $1400{ }^{\circ} \mathrm{C}$ [42] under inert gas atmosphere at varying reduction times.

The equilibrium behaviors of $\mathrm{Co}, \mathrm{Ni}$ and $\mathrm{Cu}$ in nickel and copper slag cleaning conditions have been investigated quite broadly for evaluating the metal value losses and their behaviors. Toscano and Utigard [43] investigated nickel, copper and cobalt in nickel converting conditions in the matte grade range of $1-20 \mathrm{wt} \% \mathrm{Fe}$ at $1250^{\circ} \mathrm{C}$ by injecting air or oxygen-enriched air in the liquid matte layer. Choi and Cho [44] investigated the distribution of cobalt between matte (20-80 wt $\% \mathrm{Cu}+\mathrm{Ni})$ and $\mathrm{FeO}_{\mathrm{x}}-\mathrm{SiO}_{2}$ sat. slags with different additives $\left(\mathrm{Al}_{2} \mathrm{O}_{3}, \mathrm{CaO}\right.$ and $\left.\mathrm{MgO}\right)$ at $1250-1300{ }^{\circ} \mathrm{C}$. The distribution behavior of cobalt, nickel and copper in simulated DON process (2-8 $\mathrm{wt} \% \mathrm{Fe}$ in matte) was investigated by Sukhomlinov et al. [45] at $1400{ }^{\circ} \mathrm{C}$ with $\mathrm{FeO}_{\mathrm{x}}-\mathrm{SiO}_{2}-\mathrm{K}_{2} \mathrm{O}-\mathrm{MgO}$ slags. Piskunen et al. [46] also investigated $\mathrm{Co}, \mathrm{Ni}$ and $\mathrm{Cu}$ behavior in $\mathrm{DON}$-smelting conditions between $\mathrm{FeO}_{\mathrm{x}}-\mathrm{SiO}_{2}-\mathrm{MgO}$ slags and sulfide matte in matte grade range $3-12 \%$ Fe at $1350-1450{ }^{\circ} \mathrm{C}$. Henao et al. [47-49] have reported the distribution coefficients of nickel, cobalt and copper between Ni-Fe or Ni-Fe-S and iron silicate as well as calcium ferrite slags in magnesia crucibles in the $\mathrm{pO}_{2}$ range of $10^{-10}-10^{-5}$ atm at $1500-1600{ }^{\circ} \mathrm{C}$. Font et al. [50-52] investigated cobalt, nickel and copper behavior between mattes (matte grade $0-70 \mathrm{wt} \% \mathrm{Ni}+\mathrm{Cu}$ ) and silica- or magnesia-saturated iron-silicate slags at $1300{ }^{\circ} \mathrm{C}$. Andrews \& Pistorius have investigated the behavior of cobalt in an industrial scale EF [53]. Li and Tsukihashi [54] studied the distribution equilibria of $\mathrm{Fe}, \mathrm{Co}$ and $\mathrm{Ni}$ between $\mathrm{FeO}_{\mathrm{x}}-\mathrm{SiO}_{2}-\mathrm{MgO}^{\text {sat. }}$ slag and nickel alloy at $1500-1600{ }^{\circ} \mathrm{C}$ with controlled oxygen partial pressures from $10^{-9}$ to $10^{-3}$ atm. Pagador et al. [55,56] investigated nickel, copper and cobalt distributions between $\mathrm{Ni}-\mathrm{Fe}(-\mathrm{Cu})$ alloy and $\mathrm{FeO}_{\mathrm{x}}-\mathrm{SiO}_{2}-\mathrm{MgO}^{\text {sat. }}(-\mathrm{CaO})$ slags in the $\mathrm{pO}_{2}$ range $10^{-10}-10^{-6}$ atm at $1400-1600{ }^{\circ} \mathrm{C}$. The distribution coefficient between alloy and $\mathrm{FeO}_{\mathrm{x}}-\mathrm{SiO}_{2}-\mathrm{MgO}^{\text {sat. }}$ slag at $1400^{\circ} \mathrm{C}$ and $10^{-9}$ atm was for copper 170 , for nickel 500 , for cobalt 10 and for iron 1 . Temperature increase and lime addition increased the distribution coefficients of $\mathrm{Ni}, \mathrm{Cu}, \mathrm{Co}$ and Fe. A study by Lu et al. [57] collected comprehensively the existing literature on $\mathrm{CoO}$ and $\mathrm{NiO}$ activity coefficients in multiple slag systems. They determined the activity coefficients in $\mathrm{CaO}-\mathrm{Al}_{2} \mathrm{O}_{3}-\mathrm{SiO}_{2}$ slags at different saturations $\left(\mathrm{Ni}, \mathrm{Co}\right.$ and $\left.\mathrm{Al}_{2} \mathrm{O}_{3}\right)$ at $1400^{\circ} \mathrm{C}$.

Studies on cobalt in Co-Cu [58-61], Co-Au [61,62], Co-Cu-Fe [63], Co-Au-Fe [64], Pt-Fe-Co [65] alloys equilibrated with different types of slags at $\mathrm{T}=1250-1600^{\circ} \mathrm{C}$ and $\mathrm{pO}_{2}=10^{-10}-10^{-5}$ atm have been carried out quite extensively.

The aim of this work was to investigate and improve the kinetics and recovery of cobalt, as well as nickel and copper, from nickel flash smelting slags in electric furnace (EF) environment with different reducing agents and with an addition of cobalt-rich scrap. Industrial-based nickel FSF slag 
with reductant was smelted at fixed temperature of $1400^{\circ} \mathrm{C}$ under Ar gas atmosphere with different time periods ranging from $7.5 \mathrm{~min}$ to $60 \mathrm{~min}$. The experimental drop-quench technique included smelting the samples in vertical tube furnace and fast quenching in brine/ice water mixture, followed by preliminary elemental analyses and imaging with SEM-EDS and the final concentration analyses with EPMA.

\section{Materials and Methods}

\subsection{Materials}

The inert gas atmosphere used in the experiments was achieved by feeding argon (Ar) gas (>99.998\% purity, AGA-Linde, Espoo, Finland) to the furnace with a flow rate between 300-400 mL/min, controlled by a rotameter. The cone-shaped crucibles used were made of silica glass Heraeus HSQ ${ }^{\circledR} 300$ (fused quartz with purity of $>99.998 \%$ by Finnish SpecialGlass Oy, Espoo, Finland), with a diameter of $25 \mathrm{~mm}$ and height of $15 \mathrm{~mm}$. The slag or slag-scrap mixture mass was $1.0 \mathrm{~g}$ in all experiments. This amount of slag/mixture half-filled the used crucible by visual inspection from horizontal direction. The slag used in the experiments was industrial (ground) DON smelting slag provided by Boliden Harjavalta (Harjavalta, Finland). The XRF analyses for the slag (named sample S0) were conducted initially at Boliden Harjavalta and the elemental composition results are presented in Table 1. Recycled battery scrap underflow (Akkuser Oy, Nivala, Finland) was used in some of the experiments to increase Co concentration and to see how the scrap behaves and influences the reaction kinetics and separation of metals and discard slag. The composition of the scrap can be seen in Table 2 (the elements $\leq 0.05 \mathrm{wt} \%$ were left out, except Ag and $\mathrm{Au}$ ). The battery scrap was analyzed by different techniques by Akkuser; $\mathrm{Ag}$ and Au were analyzed by ICP-MS, C by Eltra C/S analyzer, volatiles by pyrolysis, $\mathrm{F}^{-}$by pyrohydro, $\mathrm{SiO}_{2}$ by colorimetry and the other elements in Table 2 by ICP.

Table 1. Compositions of the Direct Outotec Nickel technology (DON) slag (sample S0) in wt $\%$ measured with XRF.

\begin{tabular}{cccccccccccc}
\hline $\mathrm{Fe}$ & $\mathrm{SiO}_{2}$ & $\mathrm{MgO}$ & $\mathrm{Ni}$ & $\mathrm{Al}_{2} \mathrm{O}_{3}$ & $\mathrm{CaO}$ & $\mathrm{Cu}$ & $\mathrm{Co}$ & $\mathrm{Cr}$ & $\mathrm{S}$ & $\mathrm{Zn}$ & $\mathrm{SUM}$ \\
\hline 34.3 & 34.1 & 8.7 & 4.23 & 2.7 & 1.73 & 0.65 & 0.47 & 0.097 & 0.08 & 0.05 & 87.107 \\
\hline
\end{tabular}

Table 2. Composition of the recycled battery scrap in wt\% (except Ag and Au in ppmw).

\begin{tabular}{cccccccc}
\hline $\mathbf{A g}$ & $\mathbf{A u}$ & $\mathbf{M g}$ & $\mathbf{A l}$ & $\mathbf{C a}$ & $\mathbf{M n}$ & $\mathbf{F e}$ & $\mathbf{C o}$ \\
\hline $9.5 \mathrm{ppm}$ & $2 \mathrm{ppm}$ & 0.09 & 2.16 & 0.09 & 1.65 & 0.57 & 25.5 \\
\hline $\mathbf{N i}$ & $\mathbf{C u}$ & $\mathbf{Z n}$ & $\mathbf{C}$ & $\mathbf{F}^{-}$ & $\mathbf{S i O}_{2}$ & Volatiles & \\
\hline 2.6 & 2.92 & 0.06 & 32.7 & 2.09 & 0.38 & 32.9 & \\
\hline
\end{tabular}

Two different kinds of reductants were used in the experiments: coke (Boliden Harjavalta) and spruce biochar (Carbons Finland Oy, Kouvola, Finland). The biochar was prepared by pyrolyzing at $600{ }^{\circ} \mathrm{C}$ with approximately $10 \mathrm{~min}$ holding time by the supplier and the moisture content was decreased prior to the experiments by drying it in a heating chamber at $100{ }^{\circ} \mathrm{C}$.

\subsection{Reduction Experiments}

Total of 18 experiments were conducted. The first two high-temperature experiments (S1 and S2) did not contain reductant and were made for reference purposes to obtain the starting composition of the slag and to monitor silica solubility from the crucible. Table 3 shows all the experiments conducted and their experimental parameters, such as the used reductant, scrap addition and contact time. 
Table 3. Sample numbering and series naming with the varying experimental parameters: the reductant employed, possible addition of scrap and high-temperature contact time.

\begin{tabular}{|c|c|c|c|c|c|c|c|c|c|c|c|c|c|c|c|c|c|c|c|}
\hline \multirow{2}{*}{ \# } & So & S1 & S2 & S3 & S4 & S5 & S6 & S7 & S8 & S9 & S10 & S11 & S12 & S13 & S14 & S15 & S16 & S17 & S18 \\
\hline & \multicolumn{3}{|c|}{ SLAG } & \multicolumn{4}{|c|}{ SLAG + C } & \multicolumn{4}{|c|}{ SLAG + B } & \multicolumn{4}{|c|}{ SLAG + C + SCRAP } & \multicolumn{4}{|c|}{ SLAG + B + SCRAP } \\
\hline Reductant & - & - & - & & & & & & & & & & & & & & & & \\
\hline Scrap & - & - & - & - & - & - & - & - & - & - & - & & & & & & & & \\
\hline Time (min) & 0 & 15 & 30 & 15 & 30 & 75 & 60 & 75 & 15 & 30 & 60 & 7.5 & 15 & 30 & 60 & 75 & 15 & 30 & 60 \\
\hline & & & & & & & Biocl & & & & Scrap & $(\mathrm{Co} 2$ & $5.5 \mathrm{wt}$ & & & & & & \\
\hline
\end{tabular}

As stated in Tables 1 and 2, cobalt concentrations in the slag and scrap were $0.47 \mathrm{wt} \%$ and $25.50 \mathrm{wt} \%$, respectively. For the samples with scrap addition (S11-S18), the cobalt concentration of the slag-scrap mixture was increased to $2 \mathrm{wt} \%$ by mixing and mortar grounding $15.36 \mathrm{~g}$ of FSF slag and $1 \mathrm{~g}$ of scrap to a homogenous mixture. Consequently, the scrap-containing experiments included $6.1 \mathrm{wt} \%$ of scrap in the initial mixtures. The two reductants were pre-treated differently: the coke was crushed in an agate mortar from particle size of $8-20 \mathrm{~mm}$ into smaller particles $(<1 \mathrm{~mm})$ and the biochar was dried at $100{ }^{\circ} \mathrm{C}$ for $20 \mathrm{~h}$ to reach moisture content approximately $23 \mathrm{wt} \%$, which was calculated by weighing the biochar before and after the drying. The carbon concentration in the coke was $86 \mathrm{wt} \%$, ash $11-12 \mathrm{wt} \%$ and volatiles as well as moisture $<1 \mathrm{wt} \%$, whereas the biochar contained fixed carbon $69 \mathrm{wt} \%$, ash $3 \mathrm{wt} \%$ and volatiles $4 \mathrm{wt} \%$. The specific surface area of biochar was $>500 \mathrm{~m}^{2} / \mathrm{g}$ reported by the supplier.

The drop-quench technique used in these experiments has been used extensively in phase equilibrium [66,67] and minor element equilibrium distribution studies $[68,69]$ but was utilized for kinetic research in this work, similarly as in the study of Klemettinen et al. [70] and Wan et al. [71]. The experimental vertical-tube furnace was Lenton LTF 16/450 (Lenton Furnaces \& Ovens, Hope Valley, UK) equipped with four silicon carbide heating elements, which were positioned around the $38 \mathrm{~mm}$ inner diameter alumina work tube (Frialit AL23, Friatec AG, Mannheim, Germany). A measuring thermocouple and a smaller $22 \mathrm{~mm}$ diameter alumina tube as well as the gas inlet were installed inside the work tube through a top screw. The temperature was set to $1400{ }^{\circ} \mathrm{C}$ and measured with a calibrated S-type Pt/Pt-10\%Rh thermocouple (Johnson-Matthey Noble Metals, UK, accuracy of $\pm 3{ }^{\circ} \mathrm{C}$ ) and the temperature data during the experiments was collected with a NI LabVIEW temperature logging program. The thermocouple was connected to a Keithley 2010 DMM multimeter and the room temperature was measured by a Pt100 resistance thermometer (SKS-Group, Vantaa, Finland, tolerance class B 1/10), connected to a Keithley 2000 DMM multimeter. The working tube was sealed from the bottom end with a rubber plug, which had a gas outlet tube that lead into an exhaust line. The furnace was equipped with water cooling elements at the top and the bottom parts of the working tube. A Kanthal A-wire (diameter $0.65 \mathrm{~mm}$ ) was inserted through the smaller diameter alumina tube for holding and lifting the samples from the cold end to the hot zone (the true experimental location) of the furnace.

The slag or slag-scrap mixture was weighed into the crucible and the reductant was set on top of the slag in the crucible so that it filled the rest of the crucible volume. The crucible in a basket-shaped sample holder made from Kanthal A-wire was attached to the Kanthal A-wire hanging from inside of the furnace and lifted from below to the cold zone at the lower end of the working tube. Argon gas flow was monitored through a bubble counter and channeled into the furnace from the upper end of the furnace, while the lower end was sealed with a rubber plug. The inert atmosphere was stabilized for $15 \mathrm{~min}$ before lifting the sample to the hot zone of the furnace.

At the end of an experiment, the lower end of the working tube was immersed into ice water and the plug removed without compromising the inert gas atmosphere. At the set time, the Kanthal-wire was pulled upwards, which caused the sample-basket assembly to detach and fall to the quenching bucket. The reduction times were determined by conducting two series of experiments for selected times: $15 \mathrm{~min}$ and $30 \mathrm{~min}$. Samples S1 (15 $\mathrm{min}$ ) and S2 (30 min) included only slag and samples S3 (15 $\mathrm{min}$ ) and S4 (30 min) included slag with coke as reductant (see Table 3). Based on compositional 
analysis results of the formed phases for these four samples, the two other time intervals were chosen as 7.5 and $60 \mathrm{~min}$. This time range covers all the reduction steps, from low-iron to high-iron EF matte.

\subsection{Analytical Procedure}

The crucibles were mounted in epoxy resin and after curing, the samples were cut in half, followed by another round of epoxy resin mounting and curing. The samples were then progressively ground with SiC water grinding papers from coarse to fine (P120, P240, P400, P800, P1200 and P2500) followed by diamond polishing on velvet discs utilizing 6 and $3 \mu \mathrm{m}$ diamond sprays (Struers DP Spray P, Sarasota, FL, USA) and lubricant (Struers DP-lubricant Red, Sarasota, FL, USA). The surface quality was inspected with optical microscope (Union Bi7100, Union Optical Co., Ltd., Tokyo, Japan) to ensure scratch-free sample surfaces. The samples were cleaned with ethanol in an ultra-sonic washer. The final step was to apply carbon coating on the polished surface with a carbon evaporation instrument (JEOL IB-29510VET, Peabody, MA, USA) under high vacuum. The resistance was measured from the sample surface as $<1.0 \mathrm{M} \Omega$ with a multimeter to ensure sufficient electrical conductivity for subsequent analyses. Imaging and preliminary elemental analyses were conducted with Mira 3 Scanning Electron Microscope (SEM; Tescan, Brno, Czech Republic) equipped with an UltraDry Silicon Drift Energy Dispersive X-ray Spectrometer (EDS) supplied by Thermo Fisher Scientific (Waltham, MA, USA).

The phase compositions were measured from polished sections by EPMA (Electron Probe X-ray Microanalysis) with an SX100 (Cameca SAS, Gennevilliers, France) microprobe equipped with five wavelength dispersive spectrometers (WDS). The number of EPMA analysis points in each phase of every sample was eight and the detection limits for the elements were determined separately in each analytical series and collected in Table 4. The acceleration voltage used was $20 \mathrm{kV}$ and $5-100 \mu \mathrm{m}$ spots (mainly $100 \mu \mathrm{m}$ ) were used for the glassy slag and 50-100 $\mu \mathrm{m}$ for the matte with $60 \mathrm{nA}$ emission current. Analyzed lines and standards used were as follows: $\mathrm{Si} \mathrm{K}_{\alpha}$ and $\mathrm{O} \mathrm{K}_{\alpha}$ (quartz), $\mathrm{Mg} \mathrm{K}_{\alpha}$ and $\mathrm{Ca} \mathrm{K}_{\alpha}$ (diopside), $\mathrm{Al} \mathrm{K}_{\alpha}$ (almandine), $\mathrm{Ni} \mathrm{K}_{\alpha}(\mathrm{Ni}), \mathrm{Co} \mathrm{K}_{\alpha}$ (cobaltite), $\mathrm{Cr} \mathrm{K}_{\alpha}$ (chromite), Ti K $\alpha$ (rutile), Fe $\mathrm{K}_{\alpha}$ (hematite), $\mathrm{Cu} \mathrm{K}_{\alpha}(\mathrm{Cu}), \mathrm{Zn} \mathrm{K} \mathrm{K}_{\alpha}$ (sphalerite), $\mathrm{S} \mathrm{K}_{\alpha}$ (sanidine) and $\mathrm{K} \mathrm{K}_{\alpha}$ (sanidine). $\mathrm{Ni}$ and $\mathrm{Cu}$ were synthetic $100 \mathrm{wt} \%$ metals, others were naturally occurring minerals. Totals of the individual analysis points obtained with EPMA were typically within $100 \pm 3 \%$. The PAP-ZAF matrix correction [72] by Cameca was used for the primary WDS data.

Table 4. Electron Probe X-ray Microanalysis (EPMA) detection limits in ppmw.

\begin{tabular}{ccccccccccccccc}
\hline Phase & $\mathbf{O}$ & $\mathbf{S i}$ & $\mathbf{M g}$ & $\mathbf{S}$ & $\mathbf{K}$ & $\mathbf{N i}$ & $\mathbf{C o}$ & $\mathbf{F e}$ & $\mathbf{C u}$ & Al & $\mathbf{C a}$ & $\mathbf{C r}$ & $\mathbf{Z n}$ & $\mathbf{T i}$ \\
\hline Slag & 1687 & 339 & 349 & 182 & 163 & 355 & 395 & 344 & 446 & 279 & 152 & 264 & 509 & 267 \\
\hline Matte & 1053 & 483 & 744 & 252 & 190 & 478 & 449 & 318 & 611 & 466 & 212 & 283 & 671 & 319 \\
\hline
\end{tabular}

\section{Results}

As the experiments were executed for an industrial slag combined with reductant and in some cases added battery scrap, high number of elements existed in the systems and further in the analyses. The most important elements and compounds were taken into examination and their results are presented in the following sections. The elemental results acquired by EPMA are presented in graphs as a function of reduction time for each series. Additionally, the initial slag composition values (experiment S0, see Table 3) were added at 0 min time in the result graphs. The graphs were plotted using average values of normalized compositions of the slag and matte measured by EPMA and their standard deviations $( \pm 1 \sigma)$ were used as the uncertainty values.

\subsection{Microstructure}

The microstructures of samples S10 (SLAG + B, 60min) and S13 (SLAG + B + SCRAP, $30 \mathrm{~min}$ ) are presented as backscattered electron (BSE) images obtained by SEM in Figure 1. The main matte droplets, when considering the size, were settled and found close to the bottom of the crucibles, as can 
be seen in Figure 1a,b. Some smaller matte droplets were also found in and at the edges of the slag, as well as attached to the edges of the crucible in tridymite crystals. The behavior of these droplets can be explained by the surface and interfacial tensions between the phases of the system. Matusewicz and Mounsey [27] presented that in the absence of sulfur, the resulting metal alloy has a high liquidus temperature and thus EF matte droplets are discovered to form mushy rafts difficult to settle in the slag. Entirely homogeneous and well-quenched slag areas were obtained in all samples and used for the EPMA analyses.

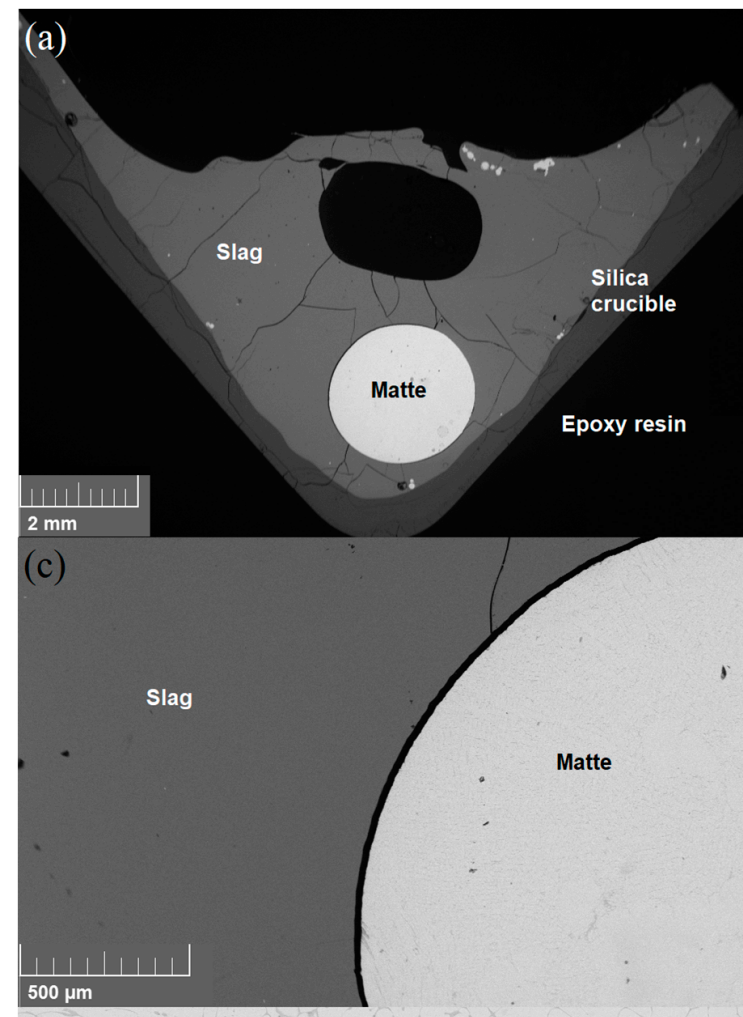

(e)
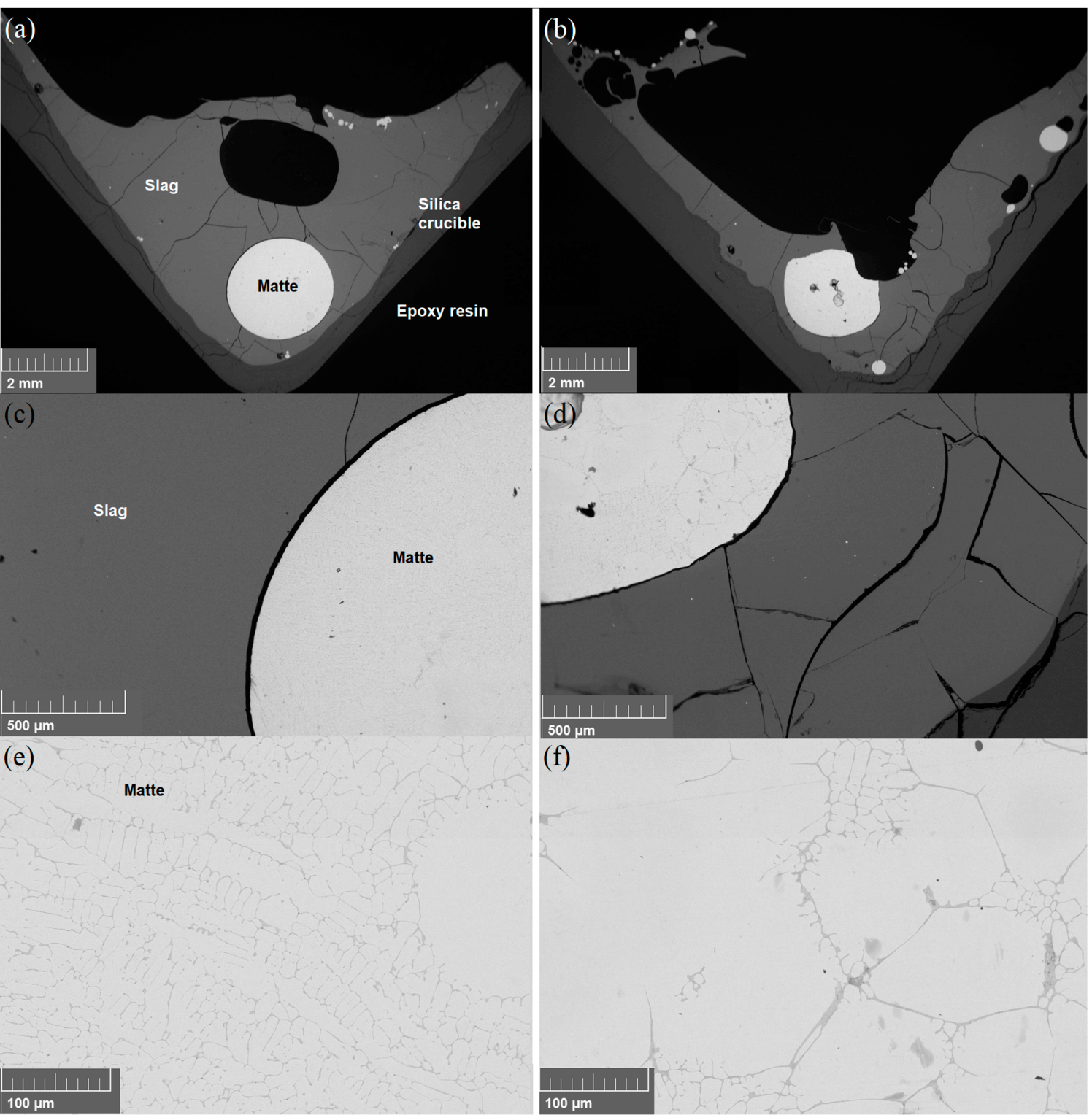

Figure 1. SEM-BSE micrographs of two samples SLAG + B (60 min, labelled (a,c,e)) and SLAG + B + SCRAP (30 min, labelled (b,d,f)).

It is known that mattes, especially sulfide mattes, are not easy to quench fast enough to form one single homogeneous phase [73]. In this work, the mattes did not form one homogeneous phase domain during quenching either; typical microstructures of mattes showing inadequate quenching rate and resulting segregation are shown in Figure 1e,f. The darker net-type microstructures had the composition of sulfur matte, whereas the seemingly more homogeneous part of the matte was almost pure metal phase. The segregated net structures were part of matte phase and thus, to get the true 
composition results, EPMA analyzes were acquired with area analysis $(50-100 \mu \mathrm{m})$ including both matte structures.

\subsection{Slag Composition}

In nickel matte smelting process, the main slag composition can be described with the Fe-O-MgO-SiO system. The DON-process slag contains also relatively high concentrations of $\mathrm{Ni}(2-5 \mathrm{wt} \%), \mathrm{Cu}(0.5-1 \mathrm{wt} \%)$ and $\mathrm{Co}(\sim 0.5 \mathrm{wt} \%)[74,75]$ depending on the raw materials used and the process practices (smelting end-point) employed. Additionally, basic and amphoteric oxides of $\mathrm{Al}_{2} \mathrm{O}_{3}, \mathrm{CaO}$ and $\mathrm{K}_{2} \mathrm{O}$ are typically present in the raw materials and due to their thermodynamic features in the process conditions, they dissolve in the slag. Figure 2 presents the $\mathrm{Fe} / \mathrm{SiO}_{2}$ ratio of the slag, which is an important operational parameter. In the DON smelting process, the ratio varies between 1-1.5 (w/w), whereas in the slag cleaning stage it is around $1[74,75]$. All the series' with different reductants and scrap additions were collected in the figure as a function of the reduction time, with their experimental uncertainties.

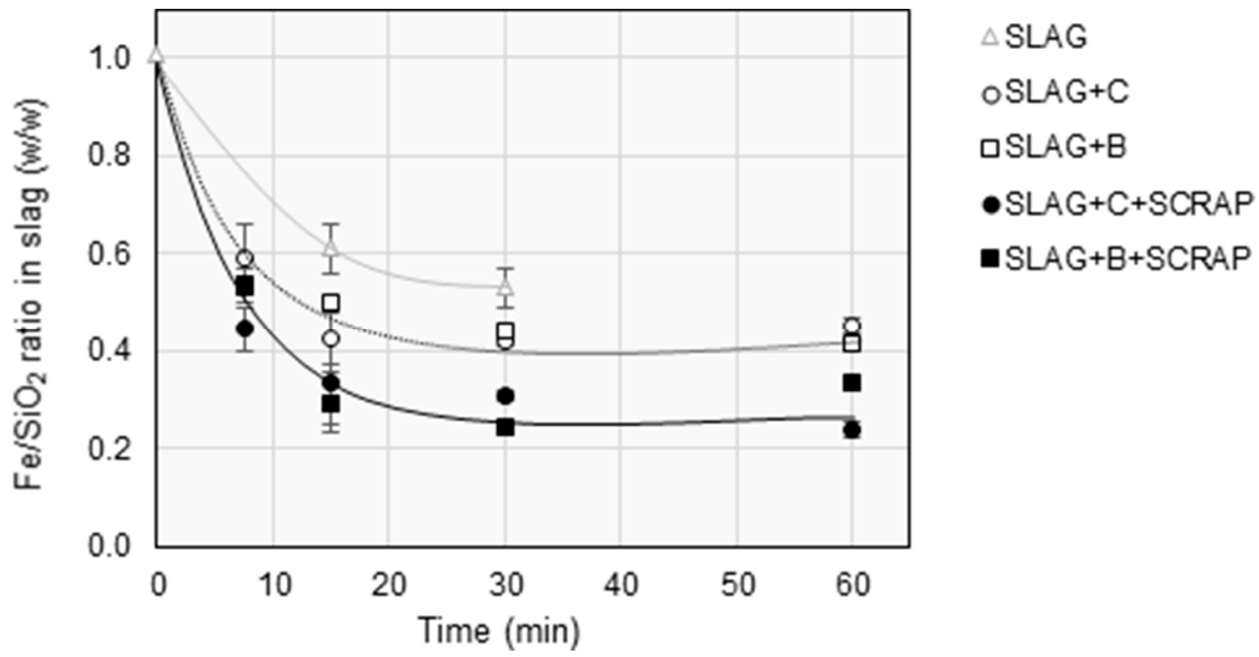

Figure 2. $\mathrm{Fe} / \mathrm{SiO}_{2}$ ratio in slag as a function of reduction time at $1400{ }^{\circ} \mathrm{C}$. Trend lines were drawn for slag melting (SLAG as solid grey line) and coke-containing reduction experiments (SLAG $+\mathrm{C}$ as dotted black line and SLAG + C + SCRAP as solid black line).

The $\mathrm{Fe} / \mathrm{SiO}_{2}$ ratios have decreasing trends up to $30 \mathrm{~min}$ of reduction, after which they become almost constant. The melting of the slag (without reductant) represents the highest ratios, starting from 1 (S0 being the ratio in the initial DON slag) and decreasing down to 0.5 at $30 \mathrm{~min}$. The ratio was mainly influenced by the dissolution of silica from the crucible, which occurred relatively quickly as can be seen in Figure 2. The uncertainties were greater for the shorter (7.5 and $15 \mathrm{~min}$ ) experiments, whereas for the longer durations the systems were almost stabilized close to their equilibrium states with small standard deviations. The battery scrap addition seemed to decrease the ratio by 0.1 when compared to the experiments without scrap. No clear influence of the used reductants, coke or biochar, on the $\mathrm{Fe} / \mathrm{SiO}_{2}$ ratio was visible in the results.

Figure 3 collects the behavior of three main oxidic components (after silica and iron oxides) in the slags as a function of reduction time. $\mathrm{K}_{2} \mathrm{O}$ concentration was around 1-1.4 wt $\%$, being on the lower side in the scrap-free slags and on the higher side in the scrap-containing slags. Additionally, the slag contained traces of typical nickel ore metals: chromium $(0.1 \mathrm{wt} \%)$, zinc $(0.01-0.08 \mathrm{wt} \%)$ and titanium (0.06-0.1 wt\%). 


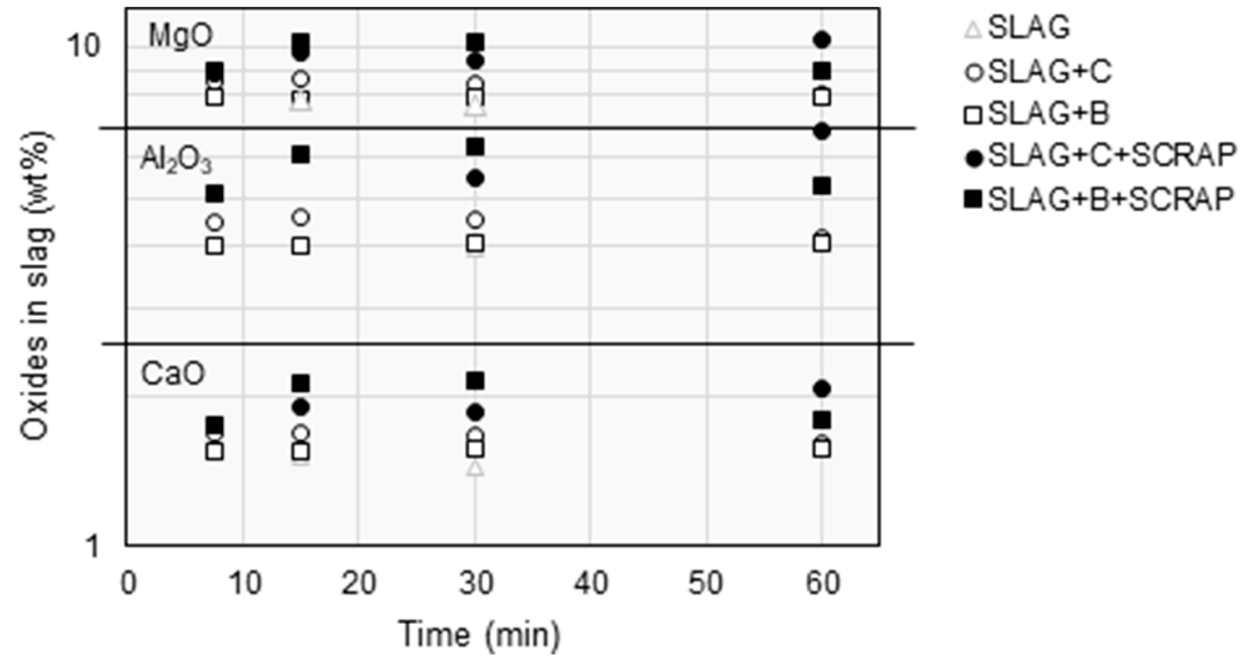

Figure 3. $\mathrm{CaO}, \mathrm{Al}_{2} \mathrm{O}_{3}$ and $\mathrm{MgO}$ concentrations in slags as a function of reduction time at $1400{ }^{\circ} \mathrm{C}$.

Magnesia concentration in slag varied between $8-10 \mathrm{wt} \%$, alumina between $4-6 \mathrm{wt} \%$ and lime between $1.5-2 \mathrm{wt} \%$. If ignoring the $\mathrm{S} 0$ sample, the concentrations of each component were relatively constant throughout the investigated time period for the reduction experiments without scrap addition. Nevertheless, it seems that with scrap addition the concentrations took longer, around $15 \mathrm{~min}$, to stabilize. Moreover, the addition of battery scrap increased the concentrations of these components in the slags by $30-50 \%$ when compared to the scrap-free slags.

Figure 4 presents nickel, copper and cobalt concentrations in slags as a function of reduction time. The initial nickel and copper concentrations calculated for the slag-scrap mixture were 4.1 and $0.8 \mathrm{wt} \%$, respectively. Those were relatively close to their initial concentrations in the industrial DON slag, thus they are not marked separately in the figures. Nevertheless, for cobalt the difference was noticeable and thus, Figure 3 has two starting values at $0 \mathrm{~min}$. For nickel, the uncertainties were included only for scrap-free systems because the nickel concentration was close or even below the detection limit of EPMA in the scrap-containing series after $15 \mathrm{~min}$ of reduction. The trend lines were drawn for coke-containing experiments.

Nickel, copper and cobalt concentrations in slags decreased until 30 min of reduction, after which they evened out. For the SLAG + B + SCRAP system, the stable concentration levels were reached faster, in $15 \mathrm{~min}$. The choice of reductant and battery scrap addition have clear influences on the behaviors of these metals in slags. When melting the slag without reductant and scrap for $30 \mathrm{~min}$, the concentrations decrease around $20-30 \%$ from their original values due to silica dissolution from the crucible. For nickel, $30 \mathrm{~min}$ reduction by coke or biochar decreased the concentration down to $0.1 \mathrm{wt} \%$ or $0.02 \mathrm{wt} \%$, respectively. Therefore, biochar provided clearly better reduction, that is, lower nickel losses in the slag. The addition of battery scrap decreased the nickel concentration in slags further, especially for the coke reduction the influence was significant, lowering the nickel concentration by one order of magnitude. In the biochar experiments, the nickel concentrations decreased close or below the detection limit of EPMA. For copper, 30 min reduction by coke or biochar decreased the copper concentration in slag down to $0.1 \mathrm{wt} \%$. Although both reductants provided relatively similar results, the concentrations obtained with coke seem to be slightly higher throughout the reduction period. The scrap addition clearly decreased the copper losses in slags with both reductants, by dropping the concentrations to half from the scrap-free experiments. The choice of reductant did not have a clear influence on copper losses in slags for the scrap-containing experiments. 

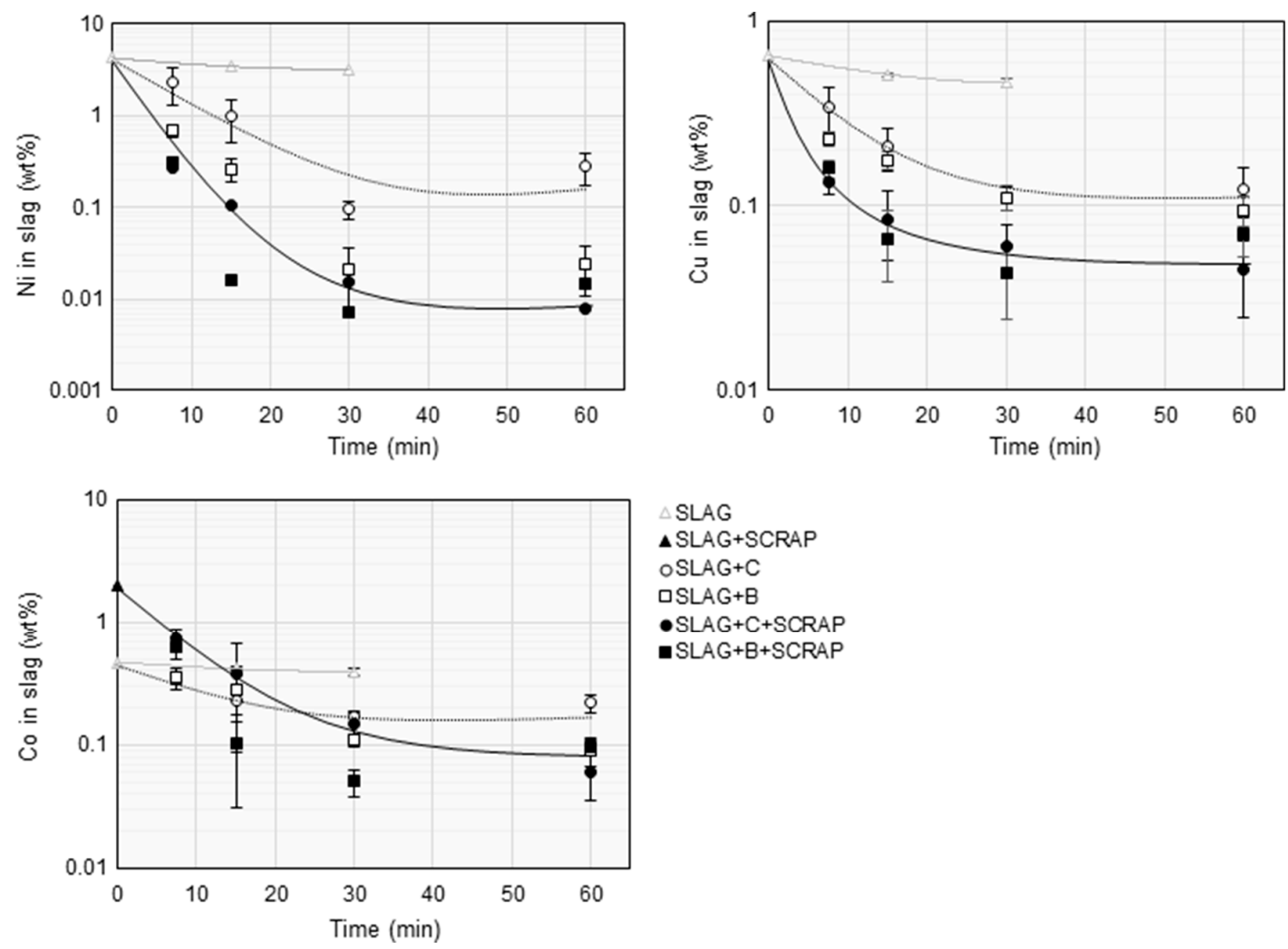

Figure 4. Nickel, copper and cobalt concentrations in slags as a function of reduction time at $1400^{\circ} \mathrm{C}$. The calculational concentration of cobalt in initial slag-scrap mixture ( $2 \mathrm{wt} \%)$ was added with symbol $\boldsymbol{\Delta}$ Trend lines were drawn for slag melting (SLAG as solid grey line (-)) and coke-containing reduction experiments (SLAG + C as dotted black line $(\cdots)$ and SLAG + C + SCRAP as solid black line (-)).

The losses of copper and cobalt in slags after 30 min reduction were in the same concentration levels, $0.1-0.2 \mathrm{wt} \%$, independent of the used reductant. Nevertheless, the initial cobalt concentration in slag was lower than that of copper. Thus, coke as a reductant had greater reduction impact on copper. The use of biochar as reductant seemed to have a slight positive influence on decreasing the cobalt concentration in slag. The addition of scrap increased the initial cobalt concentration significantly from $0.45 \mathrm{wt} \%$ to $2 \mathrm{wt} \%$ and this is clearly visible in the graph at the shorter reduction time. Yet, after 15 or $30 \mathrm{~min}$ by biochar or coke reduction, respectively, cobalt concentration in the slag was decreased to the same level or even lower as with the biochar reduction without scrap addition. Thus, addition of scrap improved the reduction and/or settling of cobalt, independently of the initial cobalt concentration, the final concentrations in slags were approximately $0.1 \mathrm{wt} \%$. It has been shown that the extracted recovery-\% in metal alloy for copper and cobalt are dependent on the initial slag composition and their concentrations in it $[35,76]$ and thus controlled by thermodynamics.

\subsection{Matte Composition}

The EF matte can be described with the Fe-Ni-Cu-Co-S system. The sulfur concentration is much lower in EF matte compared to the smelting stage matte, making it more like a metal alloy. During the slag cleaning, sulfur (nickel concentrate) is introduced into the matte layer in order to keep the matte liquid. In this study, matte was formed freely from the slag, without concentrate addition. Matusewicz and Mounsey [27] proposed that a sulfur-deficient matte/alloy would result in better cobalt recovery at temperatures $>1400{ }^{\circ} \mathrm{C}$, although Sorokin et al. [36] showed improved recoveries of nickel and cobalt by sulfur-injection. When industrial slag was melted (SLAG series), no matte was found in the samples. Figure 5 presents the concentrations of all the major elements in matte as a function of reduction time, 
with the experimental standard deviations as uncertainties. Severe inconsistencies were observed for iron and nickel in the matte and the influence of reductant and scrap between different series was not as clear and accurate as with the slag results presented above. In part of the samples, the main matte droplet was not found on the polished section and the analyses have been taken from smaller droplets. The compositions may change around the sample and a greater risk for inconsistent results exists due to the kinetic nature of the study.
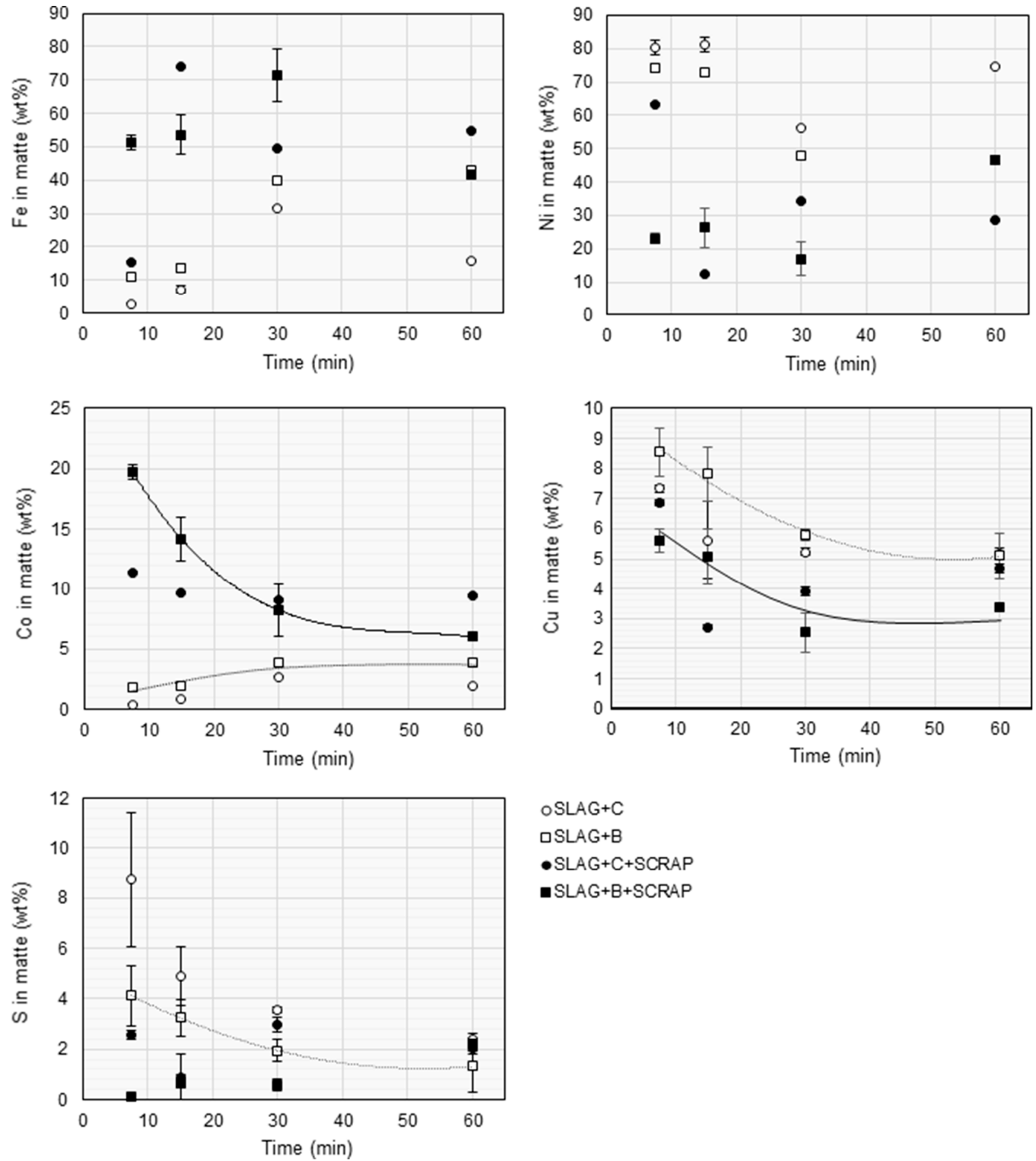

OSLAG+C

$\square S L A G+B$

- $S L A G+C+S C R A P$

- $S L A G+B+S C R A P$

Figure 5. Iron, nickel, cobalt, copper and sulfur concentrations in matte as a function of reduction time at $1400{ }^{\circ} \mathrm{C}$. Trend lines were drawn for biochar-containing reduction experiments: SLAG $+\mathrm{B}$ as dotted black line $(\cdots)$ and SLAG + B + SCRAP as solid black line $(-)$.

Iron concentration increased from around 10 to $40 \mathrm{wt} \%$ when biochar reduction of the scrap-free system proceeded, whereas with coke, the iron concentration was lower throughout the time interval investigated. With the addition of scrap, the iron results were scattered staying at relatively constant 
average level of 50-70 wt\% with both reductants. Cobalt concentration, in the experiments without scrap, showed small increasing trend up to $30 \mathrm{~min}$, after which it was stabilized. Biochar provided somewhat higher cobalt concentrations than coke. Scrap addition increased the cobalt concentration to 12 and $20 \mathrm{wt} \%$ at $7.5 \mathrm{~min}$ reduction with coke and biochar, respectively. Both series had decreasing trends as the reduction time increased, although with coke the concentration decrease was not as radical. At $60 \mathrm{~min}$ reduction, the cobalt concentration with coke was decreased down to $9 \mathrm{wt} \%$, whereas with biochar it was decreased down to $6 \mathrm{wt} \%$.

Iron and cobalt concentrations in matte were higher when scrap was added, whereas nickel and copper were lower. Nickel concentration decreased from around 75 to $50 \mathrm{wt} \%$ as biochar reduction $($ SLAG + B) proceeded, whereas in the coke reduction (SLAG $+C$ ), the nickel concentration stayed on the higher side of the biochar results, between 80 and $60 \mathrm{wt} \%$. Either of the reductant series with the scrap addition did not exhibit clear trends but stayed approximately between 20-40 wt $\%$ Ni. The concentration of copper decreased as the reduction proceeded for all systems. With short times, biochar reduction without scrap addition provided somewhat higher $\mathrm{Cu}$ concentrations in matte than coke but after $30 \mathrm{~min}$ both reductants provided similar values (5-6 wt $\% \mathrm{Cu}$ ). With scrap addition, the copper concentration in matte was between $3-7 \mathrm{wt} \%$, providing $30 \%-50 \%$ lower solubilities in matte compared to systems without scrap addition. Sulfur and nickel behaved opposite to the other metals, providing the highest concentrations with coke reduction, not with biochar. When scrap was added, the sulfur trend was not as clear as for the metals, nevertheless showing typically higher concentrations with coke than with biochar.

\section{Discussion}

The behavior of the elements in the investigated systems under reduction can be described and compared with their matte-slag distribution coefficients. Moreover, this parameter provides indications on the progress of the reaction kinetics. The distribution coefficient, $\mathrm{L} / \mathrm{s}$, is fundamentally a thermodynamic parameter, related to the properties of the system and its species. It was calculated with the following Equation (1):

$$
\mathrm{L}^{\mathrm{m} / \mathrm{s}} \equiv[\mathrm{wt} \% \mathrm{Me}] /(\mathrm{wt} \% \mathrm{Me}),
$$

where the brackets [ ] refer to element Me concentration in the EF matte and parentheses ( ) to that in the slag as $w \mathrm{t} \%$. The elemental concentrations for both phases were taken from the EPMA results and the uncertainties of the distribution coefficient values were calculated with Equation (2) [77]:

$$
\Delta \mathrm{L}^{\mathrm{m} / \mathrm{s}}=\left(\left[\Delta \mathrm{Me} / \mathrm{wt}^{\mathrm{o}} \% \mathrm{Me}\right]+(\Delta \mathrm{Me} /(\mathrm{wt} \% \mathrm{Me})) \times \mathrm{L}^{\mathrm{m} / \mathrm{s}}\right.
$$

where $\triangle \mathrm{Me}$ indicates the standard deviation of EPMA results for element Me and the wt $\%$ Me the average concentration on the element. Figure 6 collects the matte-slag distribution coefficients of nickel, cobalt, copper and iron, as a function of reduction time at $1400^{\circ} \mathrm{C}$. The reference study [41] in Figure 6 investigated the reduction of a DON-slag mixed with $0.8 \mathrm{wt} \%$ of nickel concentrate under a $\mathrm{CH}_{4}$ $(5 \mathrm{vol} \%)-\mathrm{N}_{2}$ atmosphere at $1400{ }^{\circ} \mathrm{C}$. The sample size was around $8 \mathrm{~g}$, so multiple times greater than in this study making the comparison suggestive. The samples were also quenched slowly, resulting in more heterogeneous phase structures and the concentration analyses were performed with EDS (Energy Dispersive Spectroscopy), which has higher detection limits than EPMA. These factors introduced somewhat higher errors in the results of Ruismäki et al. [41] compared to this study. The high detection limits of EDS were the reason why Ruismäki et al. presented nickel distribution coefficient results only for 2.5 and $5 \mathrm{~min}$ of reduction. Additionally, the cobalt results of a kinetic study [42] executed for DON-slag mixed with graphite-containing froth flotation fraction from LIB scraps at $1400{ }^{\circ} \mathrm{C}$ under inert gas atmosphere were added in the figure. 

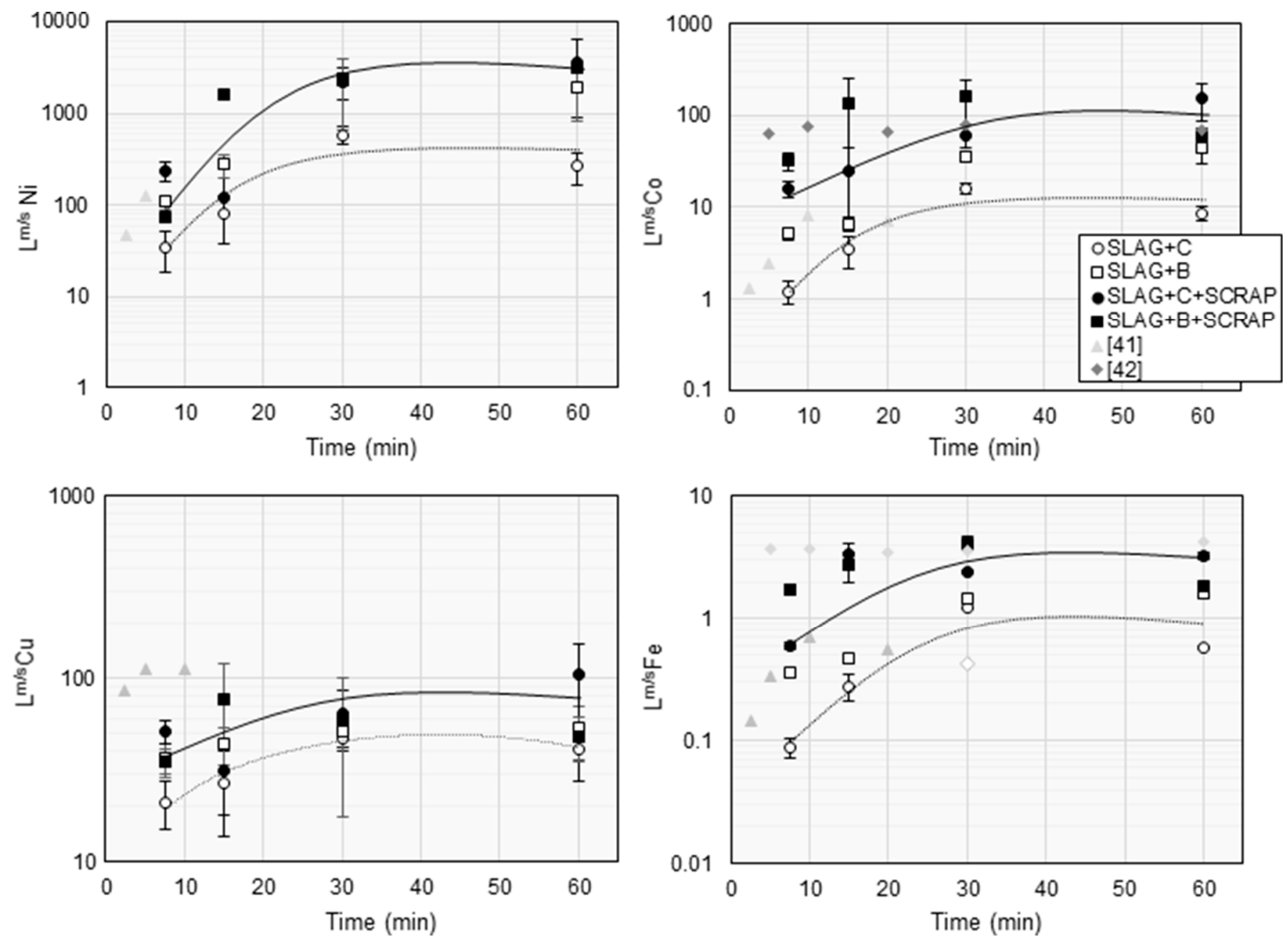

Figure 6. Matte-slag distribution coefficients of nickel, cobalt, copper and iron as a function on reduction time at $1400{ }^{\circ} \mathrm{C}$. Trend lines were drawn for coke-containing reduction experiments: SLAG $+\mathrm{C}$ as dotted black line $(\cdots)$ and SLAG + C + SCRAP as solid black line $(-)$.

The distribution coefficients of all metals in Figure 6 increased as a function of time up to $30 \mathrm{~min}$, after which they stabilized. The increase occurred due to the progress of reduction reactions; the stabilization of the system seemed to be quicker when scrap was added. This is due to the improved reduction kinetics or enhanced settling and separation of the matte and slag when scrap was added in the system.

The distribution coefficients of all the valuable metals nickel, copper and cobalt were the lowest with coke reduction, although also the distribution coefficient of iron was the lowest. The use of biochar as a reductant in the scrap-free systems increased the distribution coefficients of all metals, especially nickel, cobalt and iron and thus their yields in the EF slag cleaning. The scrap addition also had a clearly increasing effect on the distribution coefficients of all metals, enhancing the reduction kinetics and/or the phase separation. In the scrap-containing systems, both reductants provided similar distribution results and thus, the choice of the reductant is not as critical for the investigated metals, especially after $30 \mathrm{~min}$ reduction period. Nickel had the highest distribution coefficient values (up to 3000) and thus, the best recoveries in the EF matte and the lowest losses in the discard slag. Overall, after 30 min reduction the distribution coefficient order for different series were as following:

$$
\text { Coke reduction }\left(\text { SLAG }+\mathrm{C} \text { ): } \mathrm{L}^{\mathrm{m} / \mathrm{s}} \mathrm{Ni} 400>\mathrm{L}^{\mathrm{m} / \mathrm{s}} \mathrm{Cu} 40>\mathrm{L}^{\mathrm{m} / \mathrm{s}} \mathrm{Co} 10>>\mathrm{L}^{\mathrm{m} / \mathrm{s}} \mathrm{Fe} 1 .\right.
$$

Biochar reduction $(\mathrm{SLAB}+\mathrm{B}): \mathrm{L}^{\mathrm{m} / \mathrm{s}} \mathrm{Ni} 2000>>\mathrm{L}^{\mathrm{m} / \mathrm{s}} \mathrm{Cu} 50>\mathrm{L}^{\mathrm{m} / \mathrm{s}} \mathrm{Co} 40>>\mathrm{L}^{\mathrm{m} / \mathrm{s}} \mathrm{Fe} 2$

Scrap-containing reductions (SLAG $+\mathrm{B}$ or $\mathrm{C}+\mathrm{SCRAP}): \mathrm{L}^{\mathrm{m} / \mathrm{s}} \mathrm{Ni} 3000>>\mathrm{L}^{\mathrm{m} / \mathrm{s}} \mathrm{Co} 100>$

$$
\mathrm{L}^{\mathrm{m} / \mathrm{s}} \mathrm{Cu} 70>>\mathrm{L}^{\mathrm{m} / \mathrm{s}} \mathrm{Fe} 4 .
$$


Figure 6 shows that when using biochar for the DON-slag reduction, higher distribution coefficients for $\mathrm{Ni}, \mathrm{Co}$ and $\mathrm{Cu}$ were attained compared to coke and thus also better recoveries in matte. Similarly, the addition of scrap had a positive, increasing influence on the distribution coefficients with both reductants. Nevertheless, also the distribution coefficient of iron was increased, producing iron-richer EF matte that results in a greater matte production (by weight and volume) to be tapped from the furnace, wherein the valuable metals are present at lower concentrations.

If the EF matte is too high in iron, it may cause problems in downstream process steps. On the other hand, the slag cleaning stage depends on the DON smelting cycle and thus, a quicker reduction would enable more flexible operation and overall, more uniform EF matte quality. To compare more deeply the EF matte quality produced with different reductants and addition of scrap, the distribution coefficients of cobalt, copper and nickel were plotted as a function of iron concentration in the matte (wt\% $\mathrm{Fe})$, see Figures 7-9. Additionally, previous equilibrium studies $[43,45,46,48,49,54,78]$ investigating the behavior of nickel, cobalt and copper between nickel matte and slags were included in the figures, as well as the kinetic studies by Ruismäki et al. [41,42]. These studies were executed with different slag systems and temperatures, as presented in the Introduction-section. There seem to be two experiments (S12 and S15) in the scrap-containing systems that systematically deviate downwards from trends of the other experiments in this study. The reduction paths, that is, the distribution coefficients related to the matte grade (Fe in matte) in this study, seem to follow the equilibrium study results surprisingly closely, indicating thermodynamic control of the development of the matte assay during the reduction.

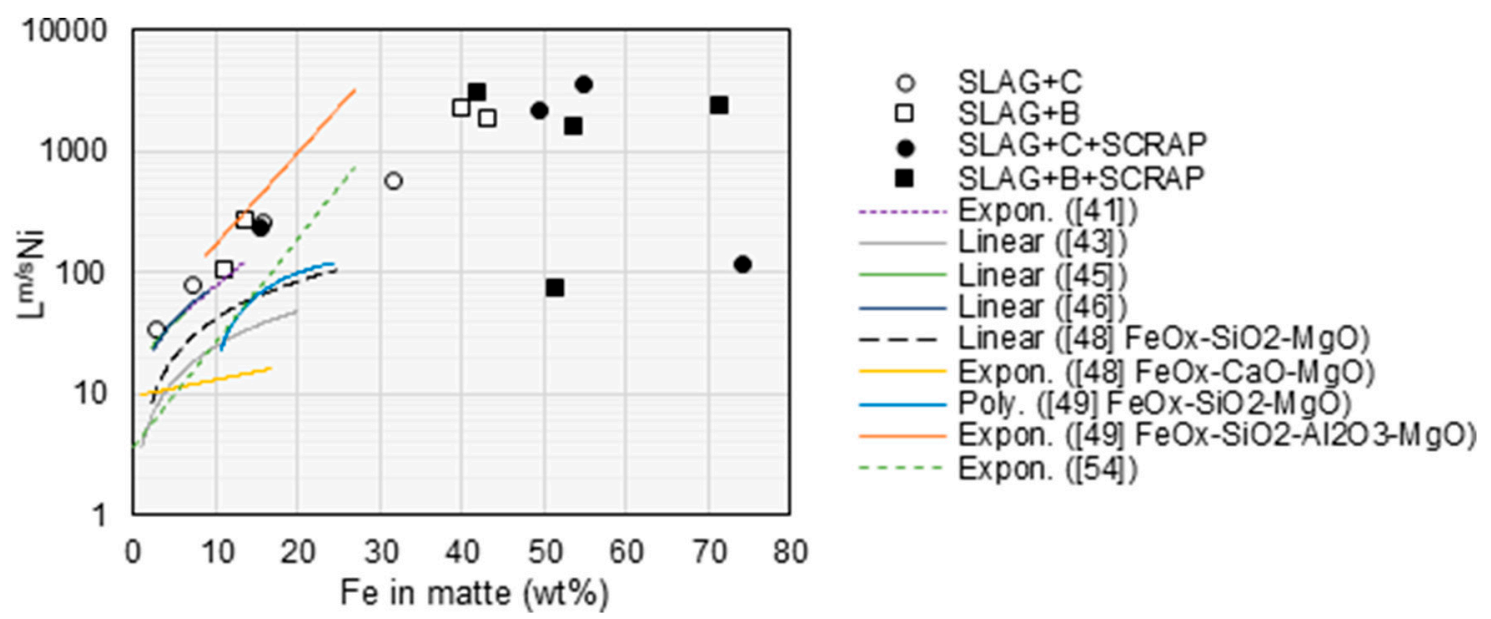

Figure 7. The distribution coefficient of nickel between matte and slag as a function of matte grade at $1400^{\circ} \mathrm{C}$. Multiple other equilibrium studies $[43,45,46,48,49,54]$ and kinetic study by Ruismäki et al. [41] were added in the figure.

The distribution coefficients of $\mathrm{Ni}, \mathrm{Cu}$ and $\mathrm{Co}$ increase along with decreasing matte grade (increasing iron concentration) in all the studies compared in Figures 7-9. This was due to the diluting effect of iron entering the matte when the prevailing oxygen partial pressure decreased. In this study, the distribution coefficient of nickel stabilized into values of 2000-3000 after reaching the matte grade $40 \mathrm{wt} \% \mathrm{Fe}$, whereas the copper distribution coefficient stabilized into value of 50-60 already at $15 \mathrm{wt} \%$ Fe in matte. The distribution coefficient of cobalt increased up to matte grade of $55 \mathrm{wt} \% \mathrm{Fe}$, leading to a $\mathrm{L}^{\mathrm{m} / \mathrm{s}}$ Co value of 150 . 


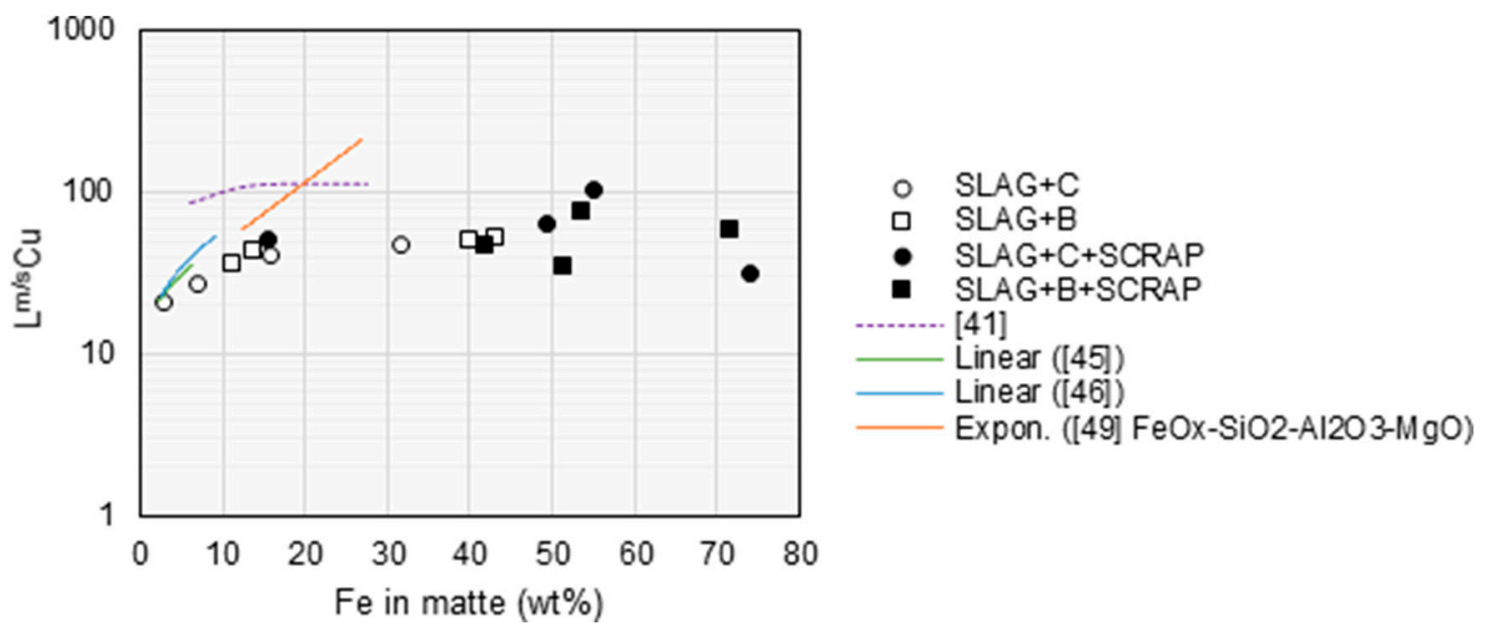

Figure 8. The distribution coefficient of copper between matte and slag as a function of matte grade at $1400{ }^{\circ} \mathrm{C}$. Multiple other equilibrium studies [45,46,49] and kinetic study by Ruismäki et al. [41] were added in the figure.

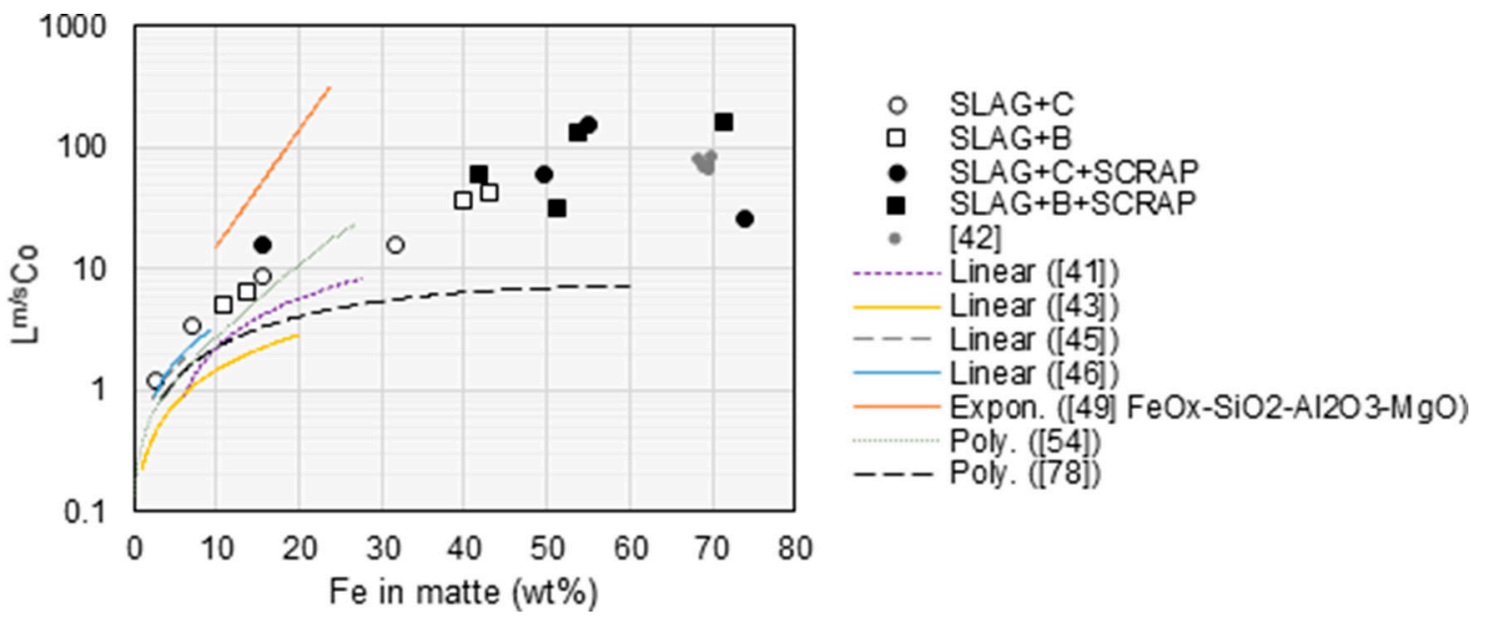

Figure 9. The distribution coefficient of cobalt between matte and slag as a function of decreasing matte grade at $1400{ }^{\circ} \mathrm{C}$. Multiple other equilibrium studies $[43,45,46,49,54,78]$ and kinetic studies by Ruismäki et al. [41,42] were added in the figure.

Most of the equilibrium studies compared have been executed in nickel smelting or converting conditions, with less than $20 \mathrm{wt} \%$ iron and higher sulfur concentration in matte than in the present study. Moreover, temperatures and the slag compositions varied between different studies, as presented in the introduction. Overall, previous studies included in the figures seemed to be relatively well comparable with each other and this study. For nickel, the distribution coefficients achieved in this study were on the higher side of most previous investigations, excluding the kinetic study by Ruismäki et al. [41] and the equilibrium study by Sukhomlinov et al. [45] and Piskunen et al. [46], which are in the same range as our results. $\mathrm{L}^{\mathrm{m} / \mathrm{s}} \mathrm{Ni}$ results for alumina-containing slag by Henao et al. [49] were somewhat higher than ours. For copper, the present results provided the lowest distribution coefficient when compared to other findings in literature. Especially in the study by Ruismäki et al. [41], copper was recovered more efficiently in the matte when compared to our copper distribution values. For cobalt, the distribution coefficients in this study were mainly on the higher side of the previous investigations. Only Henao et al. [49] achieved higher distribution coefficients for cobalt. In the other study by Ruismäki et al. [42], the distribution coefficient of cobalt reached a value of 50-80 already after 5 min, most probably due to the special reducing agent, that is, very fine particle size graphite from the battery 
scrap fraction (black mass) well mixed with the slag. The iron concentration in the metal alloy was also very high $(70 \mathrm{wt} \%)$ already after a short reduction time.

If considering the matte grade of the DON-process, in the flash smelting stage the FSF matte grade is typically around $5-7 \mathrm{wt} \% \mathrm{Fe}$ and in the slag cleaning, EF matte contains approximately $30-40 \mathrm{wt} \%$ Fe [74]. Coke and biochar reductions without scrap achieved at maximum 32 and $42 \mathrm{wt} \%$ Fe in matte, respectively. With scrap-addition, the matte grade was in minimum $42 \mathrm{wt} \% \mathrm{Fe}$ (excluding the shortest experiment with biochar). With coke reduction, the $30 \mathrm{wt} \%$ Fe matte grade was achieved in $60 \mathrm{~min}$, whereas with biochar already in less than $30 \mathrm{~min}$. This was an expected result because biochar is typically considered to have a higher reactivity. When battery scrap was added, the $30 \mathrm{wt} \% \mathrm{Fe}$ matte grade was exceeded already after 15 min with coke and biochar. Thus, control of the overall matte quality when employing scrap and/or bio-reducers will be essential for the success of the slag cleaning process. The results show that the recoveries of valuable metals in EF slag cleaning can be affected by the reduction time, the amount and quality of the used reductant and the settings (power etc.) of the furnace $[38,79]$.

The battery scrap included a high concentration of carbon ( $\sim 33 \mathrm{wt} \%)$ and its potential influence on the reduction efficiency cannot be ignored. It increased the slag/carbon ratio and interface area as the scrap was mixed with slag before the experiments. The scrap addition mainly increased cobalt and carbon concentrations in the system and the influence on the reduction by other elements and volatiles can be considered very small or even negligible. In the study of Ruismäki et al. [42], only battery scrap was used as reductant and the results regarding cobalt reduction were comparable to other studies in Figure 8 . The addition of $20 \mathrm{wt} \%$ of battery scrap after flotation, containing approximately $20 \mathrm{wt} \%$ carbon (graphite), even seemed to be excessive when considering the final iron grade in the metal alloy (approximately $70 \mathrm{wt} \%$ ). Kucharski et al. [39] found that copper recovery was slightly improved as the slag/carbon interface area was increased, although not influencing noticeably the final copper concentration in the slag. They also proposed that the geometry of the system and the slag foaming properties play a key role in the reduction surface increase.

The effectiveness of slag reduction in this study was quantified by mass balance calculations. The amount of the slag was estimated using the alumina balance and the amount of the matte from cobalt, copper and nickel balances. The yields of the metal recoveries to matte were calculated from the estimated amounts of cobalt, copper, iron and nickel in matte and slag based on the EPMA analyses of the phases. A comparison of the kinetic behaviors is shown in Figure 10.

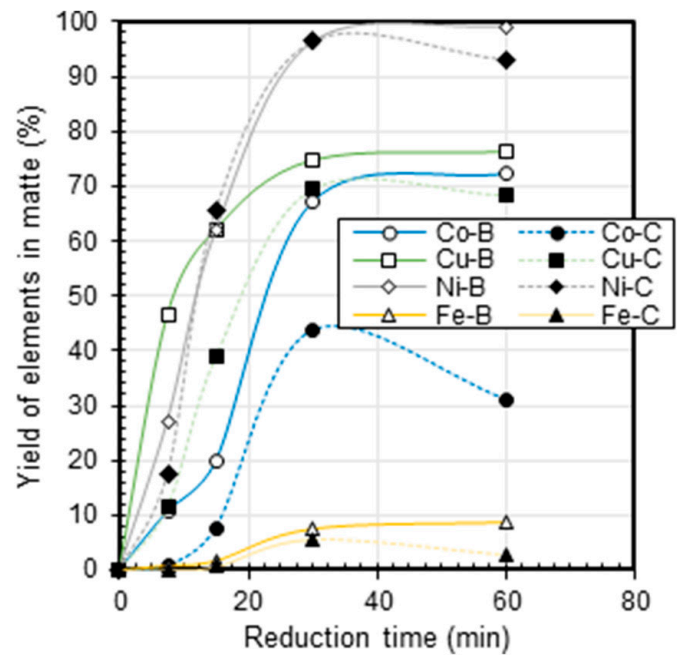

(a)

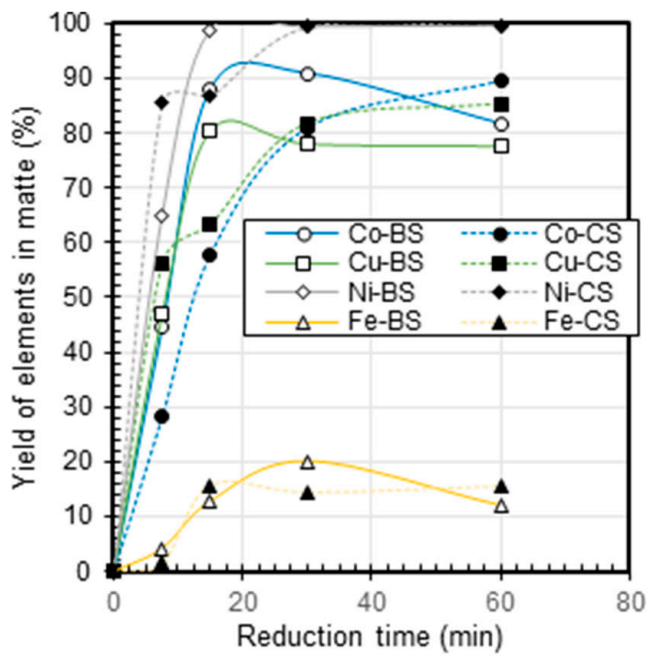

(b)

Figure 10. The metal value recoveries to matte phase in nickel slag reduction (a) yields with biochar (B) and coke (C); (b) yields with biochar, slag and battery scrap (BS) as well as coke, slag and battery scrap (CS). 
Figure 10 shows the metal recovery yields for the biochar and coke series' without Figure 10a and with Figure $10 \mathrm{~b}$ battery scrap addition. Without scrap, biochar (B) seemed to provide higher recovery yields for copper and cobalt compared to coke $(\mathrm{C})$, whereas for nickel and iron the yields are almost equal. In the scrap-containing systems (BS and CS), the used reductants have almost equal slag cleaning activities in terms of the reduction kinetics and the yield to the matte phase. The recovery of nickel in the matte was above $95 \%$, that of cobalt about $85 \%$ and copper about $80 \%$ after 30 min reduction with scrap. When the battery scrap (with high carbon concentration) was added in the slag, the reductant amount and slag-carbon contact area was increased in the initial stage, resulting in a higher reduction degree, as estimated from the yield of iron in the matte. The higher metal yields were obtained with a shorter reduction time, that is, the decrease in slag cleaning time with battery scrap additions was significant, as shown in Figure 10. The effect of a higher reduction degree in the battery scrap series is clearly seen in the case of cobalt where the series without scrap ended up in a yield between $40-70 \%$, whereas with battery scrap addition the yield was between 80 and $90 \%$ after 30 min of reduction.

\section{Summary and Conclusions}

The current megatrends of electrical transportation and renewable energy production both depend on cobalt, nickel and copper availability. With the forecasted increase in EVs and other technologies relying on cobalt, the current cobalt production needs to be tripled by 2030, to meet the demand. If the recycling and primary production of cobalt are improved, we can fight against the depletion of cobalt resources longer. In this study, the reduction kinetics and recoveries of $\mathrm{Co}, \mathrm{Cu}$ and $\mathrm{Ni}$ were investigated in nickel slag cleaning conditions by using traditional fossil-based coke and a more sustainable option, low- $\mathrm{CO}_{2}$ footprint biochar, as reductants. The experimental technique consisted of reduction experiments under inert argon gas at $1400^{\circ} \mathrm{C}$, quenching and elemental composition analyses with EPMA. Industrial DON-slag was used as the initial slag and the impact of cobalt-rich battery scrap addition was investigated. The kinetic experiments were executed in the time span of 7.5-60 $\mathrm{min}$.

Biochar improved kinetics of the slag cleaning when compared to coke; higher distribution coefficients were achieved quicker and consequently lower metal concentrations in slag, thus causing a lower matte grade (high Fe in matte). Main benefits from the industrial perspective for using biochar as a reducing agent would be a shorter reduction time, reduced dependency on fossil fuels and a decrease in the $\mathrm{CO}_{2}$ emissions. Furthermore, by improving kinetics and the yield of cobalt in the final product, the gained revenues could be increased. The iron concentration in matte was increased simultaneously with the valuables and too high iron in the EF matte may raise the costs of downstream hydrometallurgical refining [37]. Other challenges would be that biochar requires dry storage facilities and handling and the lower bulk density would limit its use in the EF. Obviously, more research concerning biochar usage in the nickel slag cleaning is needed. Different biochars should be investigated to find the optimal one for this process, different reductant/slag and biochar/coke ratios should be tested, as well as the influence of concentrate (sulfur) addition and/or stirring by submerged gas injection.

The battery scrap addition did increase the matte-to-slag distribution coefficients of the metals $(\mathrm{Cu}, \mathrm{Ni}, \mathrm{Co}$ and $\mathrm{Fe})$ in this study but consequently also the iron concentration in matte which is the thermodynamic constraint of the slag cleaning process.

Author Contributions: Conceptualization, K.A., M.J., M.M. and A.J.; methodology, K.A., M.M. and A.J.; software, K.A., M.J. and P.T.; validation, K.A., M.J., L.K., D.L., P.T. and A.J.; formal analysis, M.J. and L.K.; investigation, M.J. and K.A.; resources, D.L. and A.J.; data curation, K.A. and M.J.; writing-original draft preparation, K.A. and M.J.; writing-review and editing, L.K., M.M., P.T., D.L. and A.J.; visualization, K.A. and P.T.; supervision, A.J.; project administration, D.L. and A.J.; funding acquisition, D.L. and A.J. All authors have read and agreed to the published version of the manuscript. 
Funding: The study received financial support from the BATCircle (grant 4853/31/2018) and SYMMET program (grant 3891/31/2018) by Business Finland. L.K. is grateful for the doctoral study grant provided by the Finnish Steel and Metal Producers' Fund.

Acknowledgments: This study utilized the Academy of Finland's RawMatTERS Finland Infrastructure (RAMI) based at Aalto University, GTK and VTT in Espoo. Lassi Pakkanen at Geological Survey of Finland is greatly appreciated for conducting the EPMA analyses.

Conflicts of Interest: The authors declare no conflict of interest.

\section{References}

1. Alves Dias, P.; Blagoeva, D.; Pavel, C.; Arvanitidis, N. Cobalt Demand-Supply Balances in the Transition to Electric Mobility; Report EUR, 29381; Publications Office of the European Union: Luxembourg, 2018; p. 100.

2. European Commission written by Deloitte Sustainability; British Geological Survey; Bureau de Recherches Géologiques et Minières; Netherlands Organisation for Applied Scientific Research. Study on the Review of the List of Critical Raw Materials. Critical Raw Materials Factsheet; Publications Office of the European Union: Luxembourg, 2017; p. 93.

3. Barbera, R.J. Cobalt: Policy Options for a Strategic Mineral; Government Printing Office: Washington, DC, USA, 1982; p. 36.

4. Blechman, B.M.; Sloss, D. National Security and Strategic Minerals: An Analysis of U.S. Dependence on Foreign Sources of Cobalt; Routledge: New York, NY, USA, 2018; p. 112.

5. Scheele, F.; De Haan, E.; Kiezebrink, V. Cobalt Blues. Environmental Pollution and Human Rights Violations in Katanga's Copper and Cobalt Mines; SOMO (Centre for Research on Multinational Corporations): Amsterdam, The Netherlands, 2016; p. 57.

6. Crundwell, F.; Moats, M.S.; Ramachandran, V.; Robinson, T.G.; Davenport, W.G. Extractive Metallurgy of Nickel, Cobalt and Platinum-Group Metals; Elsevier: Oxford, UK; Amsterdam, The Netherlands, 2011; p. 610.

7. Seetharaman, S.; McLean, A.; Guthrie, R.I.L.; Sridhar, S. Treatise on Process. Metallurgy; Elsevier: Oxford, UK; Waltham, MA, USA, 2014; Volume 3, p. 1810.

8. Mäkinen, T.; Taskinen, P. State of the art in nickel smelting: Direct Outokumpu Nickel Technology. Miner. Process. Extr. Metall. 2008, 117, 86-94. [CrossRef]

9. Taskinen, P.; Seppälä, K.; Laulumaa, J.; Poijärvi, J. Oxygen Pressure in the Outokumpu Flash Smelting Furnace-Part 2: The DON Process. Transactions of the Institutions of Mining and Metallurgy Section C: Mineral. Process. Extr. Metall. 2001, 110, C101-C108. [CrossRef]

10. Toscano, P. Minimization of Dissolved Nickel and Cobalt Slag Losses at High Matte Grades. Master's Thesis, Department of Material Sciences and Engineering, University of Toronto, Toronto, ON, Canada, 2001; p. 112.

11. Jones, R.T.; Hayman, D.A.; Denton, G.M. Recovery of Cobalt, Nickel, and Copper from Slags, Using DC-Arc Furnace Technology. Pyrometallurgy Div. 1998, 2125, 1-17.

12. Ye, L.; Peng, Z.; Wang, L.; Anzulevich, A.; Bychkov, I.; Kalganov, D.; Tang, H.; Rao, M.; Li, G.; Jiang, T. Use of Biochar for Sustainable Ferrous Metallurgy. JOM 2019, 71, 3931-3940. [CrossRef]

13. Hakala, J.; Kangas, P.; Penttilä, K.; Alarotu, M.; Björnström, M.; Koukkari, P. Replacing Coal Used in Steelmaking with Biocarbon from Forest Industry Side Streams; VTT Technology Series 351; VTT Technical Research Centre of Finland: Espoo, Finland, 2019; p. 141.

14. Suopajärvi, H.; Pongracz, E.; Fabritius, T. Bioreducer Use in Finnish Blast Furnace Ironmaking-Analysis of $\mathrm{CO}_{2}$ Emission Reduction Potential and Mitigation Cost. Appl. Energy 2014, 124, 82-93. [CrossRef]

15. Zuo, Z.; Yu, Q.; Wei, M.; Xie, H.; Duan, W.; Wang, K.; Qin, Q. Thermogravimetric Study of the Reduction of Copper Slag by Biomass. J. Therm. Anal. Calorim. 2016, 126, 481-491. [CrossRef]

16. Zhou, S.; Wei, Y.; Li, B.; Wang, H. Cleaner Recycling of Iron from Waste Copper Slag by Using Walnut Shell Char as Green Reductant. J. Clean. Prod. 2019, 217, 423-431. [CrossRef]

17. Pillot, C. Lithium Ion Battery Raw Material Supply \& Demand 2016-2025. In Proceedings of the Advanced Automotive Battery Conference, Mainz, Germany, 30 January-2 February 2017; Cambridge EnerTech: Needham, MA, USA, 2017; Volume 30. Available online: http://cii-resource.com/cet/AABE-03-17/Presentations/BRMT/ Pillot_Christophe.pdf (accessed on 1 December 2020).

18. Wang, S. Cobalt-Its Recovery, Recycling, and Application. JOM 2006, 58, 47-50. [CrossRef] 
19. Zeng, X.; Li, J. On the Sustainability of Cobalt Utilization in China. Resour. Conserv. Recycl. 2015, 104, 12-18. [CrossRef]

20. Sommer, P.; Rotter, V.S.; Ueberschaar, M. Battery Related Cobalt and REE Flows in WEEE Treatment. Waste Manag. 2015, 45, 298-305. [CrossRef]

21. Georgi-Maschler, T.; Friedrich, B.; Weyhe, R.; Heegn, H.; Rutz, M. Development of a Recycling Process for Li-ion Batteries. J. Power Sources 2012, 207, 173-182. [CrossRef]

22. Zeng, X.; Li, J.; Singh, N. Recycling of Spent Lithium-Ion Battery: A Critical Review. Crit. Rev. Environ. Sci. Technol. 2014, 44, 1129-1165. [CrossRef]

23. Pinegar, H.; Smith, Y. Recycling of End-of-Life Lithium Ion Batteries, Part I: Commercial Processes. J. Sustain. Metall. 2019, 5, 402-416. [CrossRef]

24. Cobalt USGS Statistics, Annual and Monthly Publications. National Minerals Information Center. Available online: https://www.usgs.gov/centers/nmic/cobalt-statistics-and-information (accessed on 1 October 2020).

25. El-Rassi, K.P.; Utigard, T.A. Rate of Slag Reduction in a Laboratory Electric Furnace-Alternating vs. Direct Current. Metall. Mater. Trans. B 2000, 31, 1187-1194. [CrossRef]

26. Ma, S.; Han, Y. Study of Extracting Valuable Metals from Nickel Smelting Slag by a Coal-based Reduction Method. J. China Univ. Min. Technol. 2014, 43, 305-308.

27. Matusewicz, R.; Mounsey, E. Using Ausmelt Technology for the Recovery of Cobalt from Smelter Slags. J. Miner. Met. Mater. Soc. 1998, 50, 53-56. [CrossRef]

28. Jones, R.; Deneys, A. Using a Direct-Current Arc Furnace to Recover Cobalt from Slags. JOM 1998, 50, 57-61. [CrossRef]

29. Xu, S. Experimental and Modeling Study on Smelting Reduction Process. In Acta Polytechnica ScandinavicaChemical Technology and Metallurgy Series; Finnish Academy Tech Sci: Espoo, Finland, 1994; Issue 217; p. 81.

30. Hayes, P.C.; Okongwu, D.A.; Toguri, J.M. Some Observations of the Reactions between Molten Oxides and Solid Carbon. Can. Metall. Q. 1995, 34, 27-36. [CrossRef]

31. Warczok, A.; Utigard, T.A. Fayalite Slag Reduction by Solid Graphite. Can. Metall. Q. 1998, 37, 27-39. [CrossRef]

32. Heo, J.H.; Chung, Y.; Park, J.H. Recovery of Iron and Removal of Hazardous Elements from Waste Copper Slag via a Novel Aluminothermic Smelting Reduction (ASR) Process. J. Clean. Prod. 2016, 137, 777-787. [CrossRef]

33. Zhou, S.; Wei, Y.; Li, B.; Wang, H. Effect of Iron Phase Evolution on Copper Separation from Slag via Coal-Based Reduction. Metall. Mater. Trans. B 2018, 49, 3086-3096. [CrossRef]

34. Wang, Y.; Zhu, R.; Chen, Q.; Wei, G.; Hu, S.; Guo, Y. Recovery of Fe, Ni, Co, and Cu from Nickel Converter Slag through Oxidation and Reduction. ISIJ Int. 2018, 58, 2191-2199. [CrossRef]

35. Banks, C.; Harrison, D. The Recovery of Non-Ferrous Metals from Secondary Copper Smelter Discard Slags. Can. Metall. Q. 1975, 14, 183-190. [CrossRef]

36. Sorokin, M.L.; Nikolaev, G.; Komkov, A. Slag Cleaning Operation in Nickel Production. In Co-Products and Minor Elements in Non-Ferrous Smelting, Proceedings of the TMS Annual Meeting, Las Vegas, NV, USA, 12-16 February 1995; Theo Lehner; Minerals, Metals \& Materials Society: Warrendale, PA, USA, 1995; pp. 67-78.

37. Pan, J.; Zheng, G.; Zhu, D.; Zhou, X. Utilization of Nickel Slag Using Selective Reduction Followed by Magnetic Separation. Trans. Nonferr. Met. Soc. China 2013, 23, 3421-3427. [CrossRef]

38. Banda, W.; Morgan, N.; Eksteen, J. The Role of Slag Modifiers on the Selective Recovery of Cobalt and Copper from Waste Smelter Slag. Miner. Eng. 2002, 15, 899-907. [CrossRef]

39. Kucharski, M.; Sak, T.; Madej, P.; Wedrychowicz, M.; Mroz, W. A Study on the Copper Recovery from the Slag of the Outokumpu Direct-to-Copper Process. Metall. Mater. Trans. B 2014, 45, 590-602. [CrossRef]

40. González, C.; Parra, R.; Klenovcanova, A.; Imris, I.; Sánchez, M. Reduction of Chilean Copper Slags: A Case of Waste Management Project. Scand. J. Metall. 2005, 34, 143-149. [CrossRef]

41. Ruismäki, R.; Dańczak, A.; Klemettinen, L.; Taskinen, P.; Lindberg, D.; Jokilaakso, A. Integrated Battery Scrap Recycling and Nickel Slag Cleaning with Methane Reduction. Minerals 2020, 10, 435. [CrossRef]

42. Ruismäki, R.; Rinne, T.; Dańczak, A.; Taskinen, P.; Serna Guerrero, R.; Jokilaakso, A. Integrating Flotation and Pyrometallurgy for Recovering Graphite and Valuable Metals from Battery Scrap. Metals 2020, 10, 680. [CrossRef] 
43. Toscano, P.; Utigard, T. Nickel, Copper, and Cobalt Slag Losses During Converting. Metall. Mater. Trans. B 2003, 34, 121-125. [CrossRef]

44. Choi, N.; Cho, W.D. Distribution Behavior of Cobalt, Selenium, and Tellurium between Nickel-Copper-Iron Matte and Silica-Saturated Iron Silicate Slag. Metall. Mater. Trans. B 1997, 28, 429-438. [CrossRef]

45. Sukhomlinov, D.; Klemettinen, L.; Virtanen, O.; Lahaye, Y.; Latostenmaa, P.; Jokilaakso, A.; Taskinen, P. Trace Element Distributions between Matte and Slag in Direct Nickel Matte Smelting. Can. Metall. Q. 2020, 59, 67-77. [CrossRef]

46. Piskunen, P.; Avarmaa, K.; Klemettinen, L.; Johto, H.; Taskinen, P. Precious Metal Distributions in Direct Nickel Matte Smelting with Low-Cu Mattes. Metall. Mater. Trans. B 2018, 49, 98-112. [CrossRef]

47. Henao, H.; Itagaki, K. Phase Equilibrium and Distribution of Minor Elements between Ni-S Melt and $\mathrm{Al}_{2} \mathrm{O}_{3}-\mathrm{CaO}-\mathrm{MgO}$ Slag at $1873 \mathrm{~K}$. Metall. Mater. Trans. 2004, 35, 1041-1049. [CrossRef]

48. Henao, H.; Hino, M.; Itagaki, K. Phase Equilibrium between Ni-S Melt and $\mathrm{FeO}_{\mathbf{x}}-\mathrm{SiO}_{2}$ or FeO $\mathrm{F}_{\mathrm{x}}-\mathrm{CaO}$ Based Slag under Controlled Partial Pressures. Mater. Trans. 2002, 43, 2219-2227. [CrossRef]

49. Henao, H.; Hino, M.; Itagaki, K. Distribution of $\mathrm{Ni}, \mathrm{Cr}, \mathrm{Mn}, \mathrm{Co}$ and $\mathrm{Cu}$ between Fe-Ni alloy and $\mathrm{FeO}_{\mathrm{x}}-\mathrm{MgO}-\mathrm{SiO}_{2}$ Base Slags. Mater. Trans. 2001, 42, 1959-1966. [CrossRef]

50. Font, J.; Hino, M.; Itagaki, K. Phase Equilibrium and Minor Elements Distribution between Iron-Silicate Base Slag and Nickel-Copper-Iron Matte at $1573 \mathrm{~K}$ under High Partial Pressures of $\mathrm{SO}_{2}$. Mater. Trans. JIM 1999, 40, 20-26. [CrossRef]

51. Font, J.; Hino, M.; Itagaki, K. Minor Elements Distribution between Iron-Silicate Base Slag and $\mathrm{Ni}_{3} \mathrm{~S}_{2}-\mathrm{FeS}$ Matte under High Partial Pressures of $\mathrm{SO}_{2}$. Mater. Trans. JIM 1998, 39, 834-840. [CrossRef]

52. Font, J.; Takeda, Y.; Itagaki, K. Phase Equilibrium between Iron-Silicate Base Slag and Nickel-Iron Matte at $1573 \mathrm{~K}$ under High Partial Pressures of $\mathrm{SO}_{2}$. Mater. Trans. JIM 1998, 39, 652-657. [CrossRef]

53. Andrews, L.; Pistorius, P.C. Nickel, Copper and Cobalt Distribution and Equilibria in Anglo Platinum Furnace Slags. Miner. Process. Extr. Metall. 2010, 119, 52-59. [CrossRef]

54. Li, G.; Tsukihashi, F. Distribution Equilibria of Fe, Co and Ni between MgO-Saturated FeO $-\mathrm{MgO}_{\mathrm{x}} \mathrm{SiO}_{2} \mathrm{Slag}$ and Ni Alloy. ISIJ Int. 2001, 41, 1303-1308. [CrossRef]

55. Pagador, R.U.; Hino, M.; Itagaki, K. Phase Equilibrium between $\mathrm{FeO}_{\mathrm{x}}-\mathrm{MgO}-\mathrm{SiO}_{2}$ or $\mathrm{FeO}-\mathrm{CaO}-\mathrm{MgO}-\mathrm{SiO}$ Slag and Nickel Alloy. Shigen-to-Sozai 1998, 114, 127-132. [CrossRef]

56. Pagador, R.; Hino, M.; Itagaki, K. Distribution of Minor Elements between $\mathrm{MgO}$ Saturated $\mathrm{FeO}-\mathrm{MgO}_{\mathrm{x}} \mathrm{SiO}$ or $\mathrm{FeO}_{\mathrm{x}}-\mathrm{CaO}-\mathrm{MgO}-\mathrm{SiO}_{2}$ Slag and Nickel Alloy. Mater. Trans. JIM 1999, 40, 225-232. [CrossRef]

57. Lu, X.; Miki, T.; Nagasaka, T. Activity Coefficients of $\mathrm{NiO}$ and $\mathrm{CoO}$ in $\mathrm{CaO}-\mathrm{Al}_{2} \mathrm{O}_{3}-\mathrm{SiO}_{2}$ Slag and Their Application to the Recycling of Ni-Co-Fe-Based End-Of-Life Superalloys via Remelting. Int. J. Miner. Metall. Mater. 2017, 24, 25-36. [CrossRef]

58. Derin, B.; Yucel, O. The Distribution of Cobalt between $\mathrm{Co}-\mathrm{Cu}$ Alloys and $\mathrm{Al}_{2} \mathrm{O}_{3}-\mathrm{FeO}-\mathrm{Fe}_{2} \mathrm{O}_{3}-\mathrm{SiO}_{2}$ slags. Scand. J. Metall. 2002, 31, 12-19. [CrossRef]

59. Katyal, A.; Jeffes, J. Activities of Cobalt and Copper Oxides in Silicate and Ferrite Slags. In Proceedings of the 3rd International Conference on Molten Slags and Fluxes, Glasgow, UK, 27-29 June 1988; Institute of Metals: London, UK; Institute of Metals, Nort American Publications Center: Brookfield, VT, USA, 1989; pp. 46-55.

60. Wang, S.; Kurtis, A.; Toguri, J. Distribution of Copper-Nickel and Copper-Cobalt between Copper-Nickel and Copper-Cobalt Alloys and Silica Saturated Fayalite Slags. Can. Metall. Q. 1973, 12, 383-390. [CrossRef]

61. Grimsey, E.J.; Toguri, J.M. Cobalt in Silica Saturated Fayalite Slags. Can. Metall. Q. 1988, 27, 331-333. [CrossRef]

62. Wang, S.; Santander, N.; Toguri, J. The Solubility of Nickel and Cobalt in Iron Silicate Slags. Metall. Trans. 1974, 5, 261-265.

63. Kitamura, S.; Kuriyama, H.; Maruoka, N.; Yamaguchi, K.; Hasegawa, A. Distribution of Cobalt between MgO-Saturated $\mathrm{FeO}_{\mathrm{x}}-\mathrm{MgO}-\mathrm{CaO}-\mathrm{SiO}_{2}$ Slag and Fe-Cu-Co Molten Alloy. Mater. Trans. 2008, 49, 2636-2641. [CrossRef]

64. Grimsey, E.J.; Liu, X. The Activity Coefficient of Cobalt Oxide in Silica-Saturated Iron Silicate Slags. Metall. Mater. Trans. B 1995, 26, 229-233. [CrossRef]

65. Teague, K.; Swinbourne, D.; Jahanshahi, S. A Thermodynamic Study on Cobalt Containing Calcium Ferrite and Calcium Iron Silicate Slags at 1573 K. Metall. Mater. Trans. B 2001, 32, 47-54. [CrossRef]

66. Jak, E.; Zhao, B.; Hayes, P.C.; Liu, N. Experimental Study of Phase Equilibria in the System PbO-ZnO-SiO 2 . Metall. Mater. Trans. B 1999, 30, 21-27. [CrossRef] 
67. Hamuyuni, J.; Hellsten, N.; Akdogan, G.; Taskinen, P. The Liquidus in Cu-O-CaO System at Metallic Copper Saturation up to 1698 K. J. Am. Ceram. Soc. 2015, 98, 320-323. [CrossRef]

68. Shishin, D.; Hidayat, T.; Chen, J.; Hayes, P.; Jak, E. Experimental Investigation and Thermodynamic Modeling of the Distributions of Ag and Au Between Slag, Matte, and Metal in the Cu-Fe-O-S-Si System. J. Sustain. Metall. 2019, 5, 240-249. [CrossRef]

69. Avarmaa, K.; O’Brien, H.; Johto, H.; Taskinen, P. Equilibrium Distribution of Precious Metals Between Slag and Copper Matte at $1250-1350^{\circ} \mathrm{C}$. J. Sustain. Metall. 2015, 1, 216-228. [CrossRef]

70. Klemettinen, L.; Aromaa, R.; Dańczak, A.; O’Brien, H.; Taskinen, P.; Jokilaakso, A. Distribution Kinetics of Rare Earth Elements in Copper Smelting. Sustainability 2020, 12, 208. [CrossRef]

71. Wan, X.; Shen, L.; Jokilaakso, A.; Eriç, H.; Taskinen, P. Experimental Approach to Matte-Slag Reactions in the Flash Smelting Process. Miner. Process. Extr. Metall. Rev. 2020, 1-11. [CrossRef]

72. Pouchou, J.; Pichoir, L. Basic expression of "PAP" computation for quantitative EPMA. In Proceedings of the 11th International Congress on X-ray Optics and Microanalysis (ICXOM), London, ON, Canada, 4-8 August 1986; Brown, J.D., Packwood, R.H., Eds.; University of Western Ontario: London, ON, Canada, 1986; pp. 249-256.

73. Hidayat, T.; Mehrjardi, A.F.; Hayes, P.C.; Jak, E. Experimental Study of Gas/Slag/Matte/Spinel Equilibria and Minor Elements Partitioning in the Cu-Fe-O-S-Si System. Advances in Molten Slags, Fluxes, and Salts. In Proceedings of the 10th International Conference on Molten Slags, Fluxes and Salts, Seattle, WA, USA, 22-25 May 2016; Reddy, R., Chaubal, P., Pistorius, P., Pal, U., Eds.; Springer International Publishing AG: Cham, Switzerland, 2016; pp. 1207-1220.

74. Warner, A.; Díaz, C.; Dalvi, A.; Mackey, P. JOM World Nonferrous Smelter Survey Part IV: Nickel: Sulfide. JOM 2007, 59, 58-72. [CrossRef]

75. Waanders, F.B.; Nell, J. Phase Chemical Composition of Slag from a Direct Nickel Flash Furnace and Associated Slag Cleaning Furnace. Hyperfine Interact 2013, 218, 101-105. [CrossRef]

76. Whyte, R.M.; Orjans, J.R.; Harris, G.B.; Thomas, J.A. Development of a Process for the Recovery of Electrolytic Copper and Cobalt from Rokana Converter Slag. Adv. Extr. Metall. 1997, 77, 57-68.

77. Strengell, D.; Avarmaa, K.; Johto, H.; Taskinen, P. Distribution Equilibria and Slag Chemistry of DON Smelting. Can. Metall. Q. 2016, 55, 234-242. [CrossRef]

78. Font, J.M.; Hino, M.; Itagaki, K. Phase Equilibrium between $\mathrm{FeO}_{x}-\mathrm{SiO}_{2}$ Base Slag and $\mathrm{Cu}_{2} \mathrm{~S}_{-} \mathrm{Ni}_{3} \mathrm{~S}_{2}-\mathrm{FeS} \mathrm{Mattes}$ with Different $\mathrm{Cu}$ and Ni Contents at 1573 K. Shigen-to-Sozai 1999, 115, 460-465. [CrossRef]

79. Yucel, O.; Addemir, O.; Tekin, A.; Nizamoglu, S. Recovery of Cobalt from Copper Slags. Miner. Process. Extr. Metall. Rev. 1992, 10, 99-107. [CrossRef]

Publisher's Note: MDPI stays neutral with regard to jurisdictional claims in published maps and institutional affiliations.

(C) 2020 by the authors. Licensee MDPI, Basel, Switzerland. This article is an open access article distributed under the terms and conditions of the Creative Commons Attribution (CC BY) license (http://creativecommons.org/licenses/by/4.0/). 